\title{
The Economic Forces behind Deindustrialization: An Empirical Investigation ${ }^{1}$
}

\author{
Leif van Neuss ${ }^{2}$ \\ HEC - University of Liège
}

August 2, 2016

\begin{abstract}
The purpose of this paper is to provide an in-depth study of deindustrialization and to systematically analyze the reasons why the world's most economically successful countries have experienced a sharp decline in relative manufacturing employment over the last decades. A large strand of empirical literature on deindustrialization aims at quantifying the relative importance of the economic forces behind deindustrialization, especially of the 'internal' and 'external' factors. While this study does not contradict the widespread belief that internal factors are quantitatively more important in explaining deindustrialization in advanced countries taken as a whole, our results, based on both static and dynamic techniques and panel data on 18 OECD countries from 1977 to 2007, however suggest that the role of globalization may be revised upwards when resorting to appropriate and welldefined indicators of trade in manufactures.
\end{abstract}

Keywords: Structural Change, Deindustrialization

JEL Classification: 01, O3, F1, F43

\footnotetext{
${ }^{1}$ I wish to thank Lionel Artige for his valuable comments.

2 Corresponding author: HEC - University of Liège, Economics Department, Quartier AGORA, Place des Orateurs 3, B31, 4000 Liège, Belgium. E-mail: Ivneuss@ulg.ac.be
} 


\section{Introduction}

Following seminal contributions by scholars like Fisher (1939), Clark (1940) and Fourastié (1949) in the first half of the $20^{\text {th }}$ century, structural transformation or structural change, usually defined as the reallocation of economic activity across the three broad sectors agriculture, manufacturing and services ${ }^{3}$, has been the object of growing interest in the literature over the last few decades. In his Nobel Prize lecture, Kuznets (1973) even referred to structural change, a phenomenon characterized, among others, by the massive reallocation of labor out of agriculture, as one of the six main features of modern economic growth, with the latter being described as the sustained rise in productivity and living standards (Herrendorf et al., 2014). The surge of interest in structural change has relied in part on the social and economic fears associated with the process of deindustrialization, broadly defined as the secular decline in the share of manufacturing in total economy, which has particularly affected the most advanced countries since the last third of the $20^{\text {th }}$ century ${ }^{4}$. By way of illustration, the share of manufacturing in total nominal value added and employment dropped respectively from $26.6 \%$ to $18.1 \%$ and from $28.2 \%$ to $15.6 \%$ in the EU15 $5^{5}$ between 1970 and 2007 . Over the same period, the value added and employment shares of manufacturing went respectively from $23.5 \%$ to $13.1 \%$ and from $22.4 \%$ to $9.9 \%$ in the US ${ }^{6}$. In 2014, the value added share of manufacturing in the EU15 and the US is estimated to amount $15.1 \%$ and $12.1 \%$ respectively, while the employment share is equal to $13.2 \%$ and $8.1 \%$ respectively ${ }^{7}$.

The term deindustrialization definitively fell into current language with the publication of Bluestone and Harrison's (1982) famous and seminal book entitled The Deindustrialisation of America. Defining "deindustrialization" as the "widespread and systematic disinvestment in a nation's basic productive capacity" (1982:6), the authors expressed great concern about the wave of plant closings that swept through the northern US during the 1970s and the ongoing erosion of the America's industrial base, a phenomenon supposedly caused in part by a "globalization gambit" linking international capital flows and industrial investment decisions with both local and personal troubles ${ }^{8}$ (Strangleman and Rhodes,

\footnotetext{
${ }^{3}$ As pointed out by Stijepic (2011:3), the main reason why this three-sector division has been so widely used is because "it seems to be useful to explain the historical development of the industrialized economies, i.e. the transition from agriculture to manufacturing and from manufacturing to services".

${ }^{4}$ As evidenced by Palma (2014:8-9), advanced OECD countries began deindustrializing in the late 1960s, while some highincome developing countries in East Asia entered this phase in the late 1980s. More surprisingly, Latin America and Africa have also gone through a process of deindustrialization since the 1980 s and the implementation of some radical economic reforms. This has been especially marked in Latin American where the share of manufacturing in total value added dropped from $24 \%$ to $18 \%$ on average between 1980 and 2005 (Szirmai, 2012). This process of deindustrialization in Latin America and Africa has taken place at levels of economic development, measured by means of income per capita, being far lower than those of the advanced OECD countries that began deindustrializing earlier, a situation soemtimes labelled "premature deindustrialization", whose potential harmful economic consequences have been emphasized by a lerge number of scholars (see e.g. Szirmai, 2012; Imbs, 2013; Rodrick, 2015).

5 The term EU15 refers to the 15 Member States of the European Union as of December 31, 2003, prior to the accession of ten candidate countries on 1 May 2004 (OECD). It comprises the following 15 countries: Austria, Belgium, Denmark, Finland, France, Germany, Greece, Ireland, Italy, Luxembourg, Netherlands, Portugal, Spain, Sweden and the United Kingdom.

${ }^{6}$ The data is from the EU KLEMS Database.

${ }^{7}$ The data for the EU15 is from Eurostat. The data for the US is from BEA (value added) and BLS (employment).

${ }^{8}$ Bluestone and Harrison's (1982) broader account of America's deindustrialization includes elements like declining profits, anti-union management, the avoidance of taxation and welfare responsibilities, and shifting power relations between capital and labor (Brady and Denniston, 2006)
} 
2014, Strangleman 2016a). Although the phrase "deindustrialization" is nowadays commonly used to refer to the relative decline of manufacturing at national level, a process that dates back to the late 1960 s in the advanced OECD countries, it has also been increasingly resorted to by the literature to describe situations of industrial decline and economic downturn at more disaggregated geographical levels, notably at regional and city level, throughout economic history. By way of illustration, Verley (1997:79) employs the term "deindustrialization" to characterize the decline of the urban industry, and the attendant growth of commercial and financial activities, in many European cities following the development of protoindustrialization and the putting-out system, a specific mixed form of labor organization which combines rural and urban aspects, that preceded the industrial revolution ${ }^{9}$. In the same book, Verley (1997:420) also employs the term "deindustrialization" to describe the economic decline of some European proto-industrial regions, notably in France and Britain, which failed their transition to modern industry at times of the industrial revolution ${ }^{10}$. The term "deindustrialization" has also been largely used to refer to regions that industrialized over the $19^{\text {th }}$ and $20^{\text {th }}$ century based on some comparative advantage, like the presence of economically valuable natural resources (coal, iron, etc.), and finally experienced a decline in the performance of their traditional sectors because of some competitiveness loss that could result, for instance, from the emergence of a new "technical system", as it was called by Gille (1978), or growing trade (see e.g. Byrne, 1980; Taylor, 1981; Lissoni, 1996; Koistinen, 2006; Minchin, 2006;; McKee, 2008; Dandaneau, 2012; Barton, 2015).

The study of deindustrialization, understood as the relative decline in the share of manufacturing in total national employment and output, really took off in the 1980s as the scale and consequences of economic restructuring and job losses in manufacturing became much more apparent and tangible, especially in the United Kingdom and the US, thus contradicting Lawrence's (1983) early claim that deindustrialization was a myth (Strangleman and Rhodes, 2014). As recently stressed by High (2013), the scholarly focus on deindustrialization, whose multidimensional and interdisciplinary aspect has been repeatedly stressed in the scientific literature (see e.g. Pahl, 1984; Newman, 1985; Goch, 2002; Altena and Van der Linden, 2002, Cowie and Heathcott, 2003; Strangleman, 2016a and 2016b), has broadened from the causes of deindustrialization to its short and long term effects. While sociology has largely addressed the "social trauma" (Bluestone and Harrison, 1982:65) supposedly caused by relative manufacturing decline, notably through various studies analyzing the consequences of mass shutdowns upon workers and their families, as well as upon local communities, economics has rather devoted a great deal of effort to investigating the potential effects of relative manufacturing decline on employment, growth or income inequality.

What are the key economic forces behind deindustrialization? Although this research question calls for specific considerations, it is actually part of a larger discussion on the drivers of structural change. The theoretical literature has thus identified various channels through which structural change, and deindustrialization, can occur. They range from demand-side factors (see e.g. Clark, 1940; Kongsamut

\footnotetext{
${ }^{9}$ The theory of proto-industrialization, first developed by Mendels (1972), was an attempt to associate the movement of rural industrialization observed in Western Europe in the $18^{\text {th }}$ century with the creation of the "modern" industry.

${ }^{10}$ Verley (1997) puts forward different factors likely to account for these industrial failures. They include, among others, the disruption of trade flows, the loss of position revenues due to expanding geographical markets as a result of, for instance, better transport infrastructure, the lack of industrial motivation from local capital owners, the excessive energy cost, like the coal-supply cost, in a context of rising dependence of industrial activities on steam power.
} 
et al., 2001; Foellmi and Zweimüller, 2008) to technological factors (see e.g. Baumol, 1967; Baumol et al., 1985; Ngai and Pissarides, 2007; Acemoglu and Guerrieri, 2008; Alvarez-Cuadrado et al., 2015), and also include elements about the inter-sectoral division of labor (outsourcing) and international trade ${ }^{11}$. Despite the growing literature devoted to structural change, the causes of deindustrialization are however still not fully understood. In particular, the relative importance of the driving forces at work through the potential channels identified by the theoretical literature, especially of the internal and external factors, is not well established. This is partly because most previous empirical research on deindustrialization (see e.g. Wood, 1994, 1995; Saeger, 1997; Rowthorn and Ramaswamy, 1997, 1999; Alderson, 1997, 1999; Kucera and Milberg, 2003; Rowthorn and Coutts, 2004; Whitford, 2005; Brady and Denniston, 2006; Kollmeyer, 2009; Kang and Lee, 2011; Rowthorn and Coutts, 2004, 2013; Rodrik, 2015) has either ignored one or more of the explanations of deindustrialization altogether or has simply failed to test all of them simultaneously. In addition to this potential omitted variable bias, which has already been stressed by Kollmeyer (2009), we argue that the common measure of trade as a factor likely to account for deindustrialization in previous studies is inaccurate and may lead to misleading results.

Based on an up-to-date review of the literature on structural change, the main purpose of this study is to discuss some issues of debate regarding deindustrialization and to analyze the determinants of deindustrialization using a dataset covering the world's most economically successful countries over the period going from 1977 to $2007^{12}$. The paper is organized as follows. Section 2 shows evidence of relative manufacturing decline in the world's most economically successful countries since the 1970s. Section 3 provides an overview of the main factors advanced in the scientific literature to account for deindustrialization. Section 4 describes the data and the research strategy used to test the factors associated with deindustrialization. Section 5 presents the empirical results. Section 6 discusses the potential implications and consequences of deindustrialization. Section 7 gives concluding remarks.

\section{Deindustrialization: evidence for currently rich countries}

In their course of economic development, virtually all advanced countries have followed a broadly similar trajectory (Rowthorn and Coutts, 2004, 2013). Up until the $18^{\text {th }}$ century, agriculture was the most important sector in all national economies around the globe, absorbing most of the labor force and contributing most of the production. Its importance was emphasized by some highly influential economists like François Quesnay who considered agriculture as the only productive sector able to generate profits, relegating the other activities like manufacturing and trade, viewed as "sterile", to the sidelines (Kongsamut et al., 1997, 2001). As from the second half of the $18^{\text {th }}$ century, a number of

\footnotetext{
${ }^{11}$ A strand of the literature on structural change, and especially of the literature on deindustrialization, has been used to dividing the factors potentially responsible for structural change into two groups: internal and external factors. The external factors mainly relate to international trade.

12 Though internationally comparable data on economic structure in the world's most advanced economies are available up to 2011 in the EU Klems database and the OECD STAN database, we decided to restrict the period of investigation in order to exclude from the analysis the recent financial and economic crisis that swept across the world following the subprime mortgage crisis in 2007 and dramatically affected manufacturing, with potentially large effects on economic structure data.
} 
countries, especially those that are nowadays viewed as the most economically successful countries, have experienced a successful wave of industrialization. According to traditional historiography, the industrial revolution began in Britain then swept through Europe and North America, before reaching Japan and Russia by the end of the $19^{\text {th }}$ century. While the causes of the industrial revolution are still heatedly debated in the literature (see e.g. Mokyr, 1999; van Neuss, 2015), it is nevertheless widely recognized that the industrial revolution, a period that witnessed an unprecedented irise in the rates of efficiency advance (Clark, 2014), marked the starting point of modern economic growth, defined as the sustainable increase in GDP per capita, and accelerated the process of structural change. The growth of GDP per capita in successful countries has been accompanied with a fall in the agricultural share of employment and output, and a rise in the share of services. Manufacturing has moved on a different trajectory as its share in national output and employment follows a hump shape, that is, it is increasing for lower levels of economic development and decreasing for higher levels of economic development (see e.g. Buera and Kaboski, 2012a, 2012b; Herrendorf et al., 2014; van Neuss, 2016). The decreasing part of this trajectory refers to the process of "deindustrialization", a phenomenon which has particularly affected the most advanced economies since the last third of the $20^{\text {th }}$ century. As shown in figures 1 and 2, the share of manufacturing in total employment and total nominal value added has declined in all selected advanced countries since $1970^{13}$. For instance, the manufacturing share of total employment in the EU15 (US) dropped from $28.2 \%$ (22.4\%) to $15.6 \%$ (9.9\%) between 1970 and 2007. Over the same period, the share of manufacturing in total nominal value added in the EU15 (US) fell from $26.6 \%$ (23.5\%) to $18.1 \%$ (13.1\%). As shown in appendix 1, the UK seems to be the country in which manufacturing experienced the sharpest decline. The share of manufacturing in total employment and output indeed dropped respectively from $33.2 \%$ to $11.8 \%(-21.4 \%)$ and from $34.2 \%$ to $12.4 \%(-21.7 \%)^{14}$.

Figure 1: Manufacturing share of total employment, 1970-2007

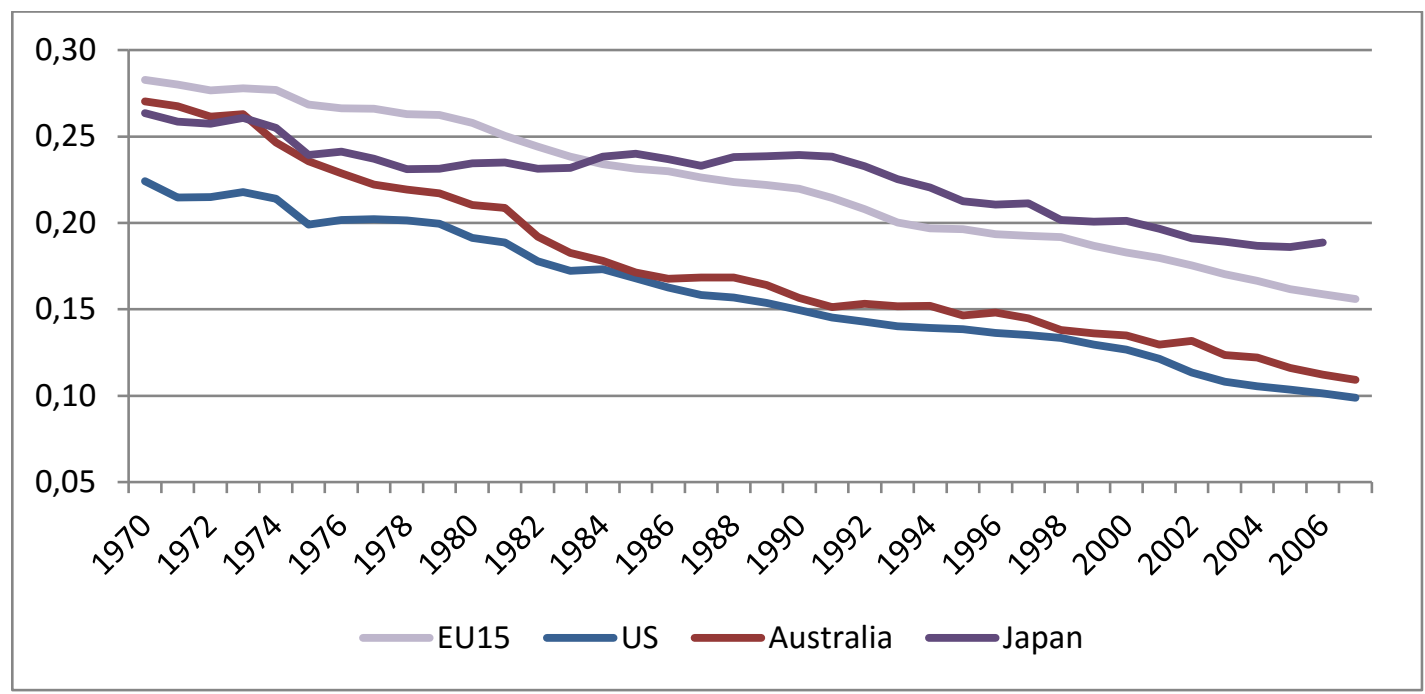

Source: EU Klems Database

\footnotetext{
13 The selection of industrial countries was driven by the availability of data in the EU Klems database.

14 The UK ranks only second in the table computing the absolute variation in the output share of manufacturing between 1970 and 2007, just behind Luxembourg where the share of manufacturing in total vnominal alue added fell from $41.1 \%$ to $8.6 \%(-32.5 \%)$, largely because of the growth of financial services.
} 
Figure 2: Manufacturing share of total nominal value added, 1970-2007

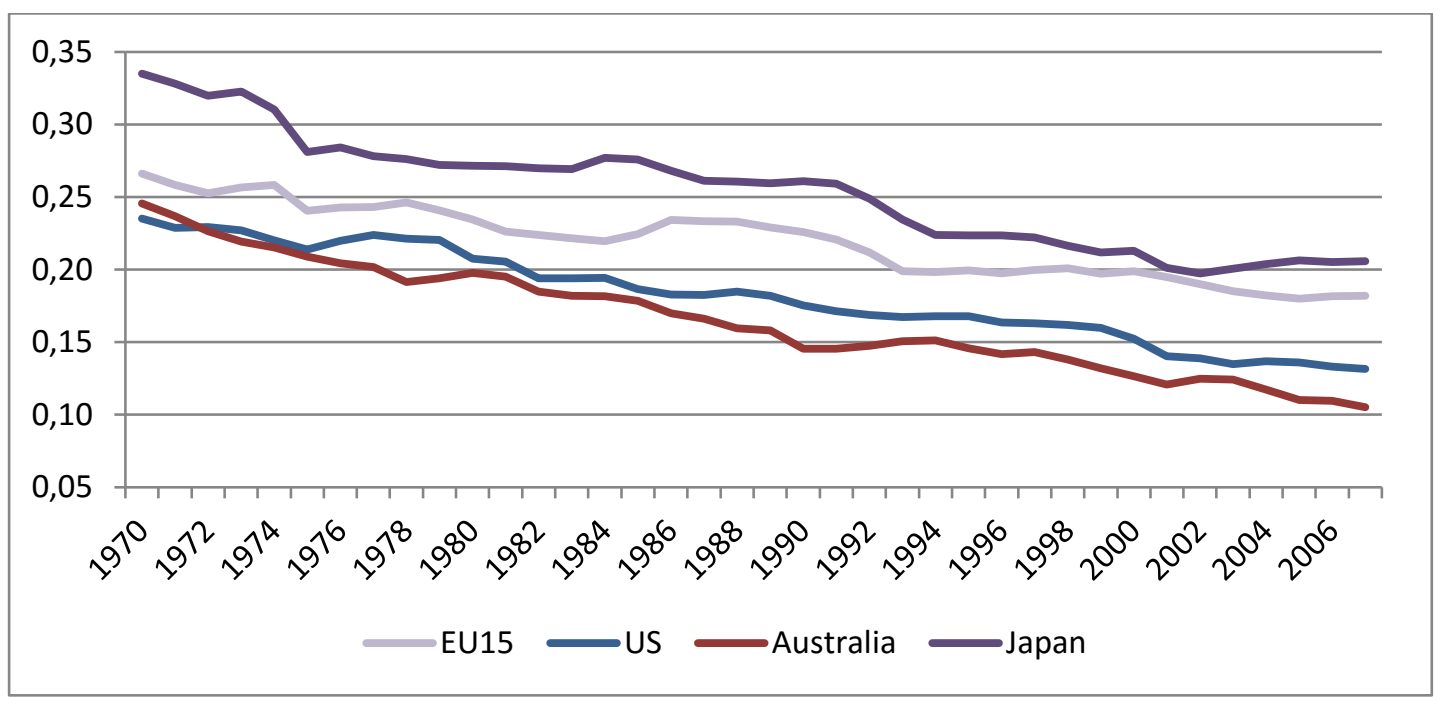

Source: EU Klems Database

While figures 1 and 2 spotlight deindustrialization in advanced countries over the few last decades, it remains to be seen whether the decline in the share of manufacturing in total economy has resulted from an absolute drop in manufacturing employment and value added or has just translated a slower growth of manufacturing compared to the rest of the economy.

Table 1: Average Annual Growth Rate of Real Value Added and Employment, 1970-2007

\begin{tabular}{|l|c|c|c|c|}
\cline { 2 - 5 } \multicolumn{1}{c|}{} & \multicolumn{2}{c|}{ Value Added } & \multicolumn{2}{c|}{ Employment } \\
\cline { 2 - 5 } \multicolumn{1}{c|}{} & Total Economy & Manufacturing & Total Economy & Manufacturing \\
\hline EU15 & $2,5 \%$ & $1,9 \%$ & $0,6 \%$ & $-1,0 \%$ \\
\hline United States & $2,9 \%$ & $2,8 \%$ & $1,6 \%$ & $-0,7 \%$ \\
\hline Australia & $3,3 \%$ & $1,5 \%$ & $1,7 \%$ & $-0,9 \%$ \\
\hline Japan & $3,2 \%$ & $3,9 \%$ & $0,5 \%$ & $-0,6 \%$ \\
\hline
\end{tabular}

Source: EU Klems Database

Table 1 reveals that manufacturing value added grew at a positive rate between 1970 and 2007 in all selected countries. While the average annual growth rate of value added in the manufacturing sector is lower than the one in the whole economy in the EU15, the US and Australia, it is remarkably higher in Japan, thus reflecting the important role of prices in the observed decline in the manufacturing share of nominal value added over the last decades (see figure 2). Manufacturing employment, by contrast, decreased in absolute terms between 1970 and 2007 in all selected countries. The EU15, where the number of manufacturing workers fell by around $1 \%$ per year on average, exhibits the largest decline, surpassing japan and the US. As shown in appendix 2 , this figure however masks some heterogeneity among European countries. While the number of manufacturing workers fell by around 0.2 per year 
on average in Italy over the period 1970-2007, it dropped by respectively $1.8 \%$ and $2.5 \%$ in Belgium and the UK. Accordingly, manufacturing employment was slashed by roughly half in Belgium (-48.4\%) and more than halved in the UK (-60.7\%). Ireland and Spain are the two only Member States where the number of manufacturing workers actually rose between 1970 and 2007, by respectively $23.1 \%$ and $11.7 \%$. It is, however, noteworthy that direct international comparisons of economic activity in the manufacturing sector may be somewhat hazardous, especially as the different countries did not begin deindustrializing at the same time (see Alderson, 1999). As shown in appendix 3, the process of deindustrialization, which can describe a wide range of national experiences (Tregenna, 2015), has not been stable over time in selected countries. For instance, employment in US manufacturing, despite a sustained growth of manufacturing value added between 1970 and 2000, was approximatively the same in 2000 as in the 1970s, then started declining in the 2000s, mirroring to some extent the growth deceleration in manufacturing output. Between 2000 and 2007, the number of workers indeed fell by nearly one-quarter in the US manufacturing sector, while value added grew by only $11.7 \%$. In Japan, manufacturing employment has been on a downtrend since the 1990s. Broadly speaking, it is possible to conclude that Europe, Australia, Japan and the US have all experienced relative deindustrialization, defined as a decline in the share of manufacturing in total employment and nominal value added, since 1970. While real value added in manufacturing has followed an upward trend with cyclical ups and downs, and truly some growth deceleration in several countries, over the last decades, manufacturing employment, by contrast, is now declining in virtually all advanced countries.

\section{Existing explanations for deindustrialization}

The economic literature has identified a range of channels through which structural change, and so deindustrialization, may occur ${ }^{15}$. In particular, it highlights four primary sources of deindustrialization, namely non homothetic preferences, cross-sector differences in technology, inter-sectoral division of labor (outsourcing) and trade. It is important to note that all these sources are not seen as mutually exclusive but complementary. As this study first seeks to analyze and quantify the economic forces behind the decline in the manufacturing share of total employment in advanced countries, this review will mainly focus on the effects of the potential driving factors on manufacturing employment.

Non-homothetic Preferences (Income Effects)

Economists have long recognized the association between the level of economic development and the sectoral structure of national employment. Based on an extrapolation of Engel's law, which states that the share of expenditures devoted to food products declines as per capita income rises, Clark (1940, 1957) even predicted deindustrialization before it became a common phenomenon in rich countries (Saeger, 1997). Through a statistical analysis of cross-national data, Clark (1957) argues that the share of income spent on manufactures should rise during the first stages of economic development then stabilize and eventually fall beyond a certain threshold of per capita income, a situation sometimes

\footnotetext{
${ }^{15}$ For general surveys of the literature on structural change, see e.g. Matsuyama (2008), Ray (2010), Herrendorf et al. (2014)
} and van Neuss (2016). 
labelled as the "Bell's (1976) Law" (see Rowthorn and Coutts, 2004, 2013). According to this view, structural change, and so deindustrialization, are driven by changes in the patterns of final demand resulting from changes in income. In technical terms, structural change is driven by non-homothetic preferences, like the well-known Stone-Geary preferences, generating non-linear Engel curves. Over the course of economic development, economic activity would then be reallocated towards the sectors providing products that respond to higher hierarchical needs. Under the assumption that productivity (TFP) growth is the same across the three broad sectors agriculture, manufacturing and services, the sequence of changes in the composition of final demand theoretically induces a curvilinear, inverted U-shaped relationship between income per capita and the manufacturing share of total employment. This account of structural change has been rigorously formalized within growth frameworks by authors like Kongsamut et al. (2001) or Foellmi and Zweimüller (2008). Providing strong micro-foundations for the use of non-homothetic preferences, Foellmi and Zweimüller (2008) thus developed a multi-sector growth model - in which new goods are continuously introduced into an original hierarchical utility function - which shows ability to reproduce the hump-shaped relationship between the manufacturing share of total employment and income, a trajectory observed in the data and confirmed by empirical research (see e.g. Rowthorn and Wells 1987; Krugman and Lawrence 1993; Rowthorn and Ramaswamy 1997, 1999; Alderson 1999; Rowthorn and Coutts 2004, 2013; Kollmeyer, 2009; Kang and Lee, 2011; Rodrik, 2015). Figure 3 plots individual time series of manufacturing employment share for a panel of 20 advanced countries over the period 1970-2007. The horizontal axis measures the log of GDP per capita in 1990 international dollars as reported by Maddison (2013). Taken as a whole, the data appear to be consistent with a hump shape for the employment share in the manufacturing sector.

Figure 3: Manufacturing Share of Total Employment, 20 OECD countries, 1970-2007

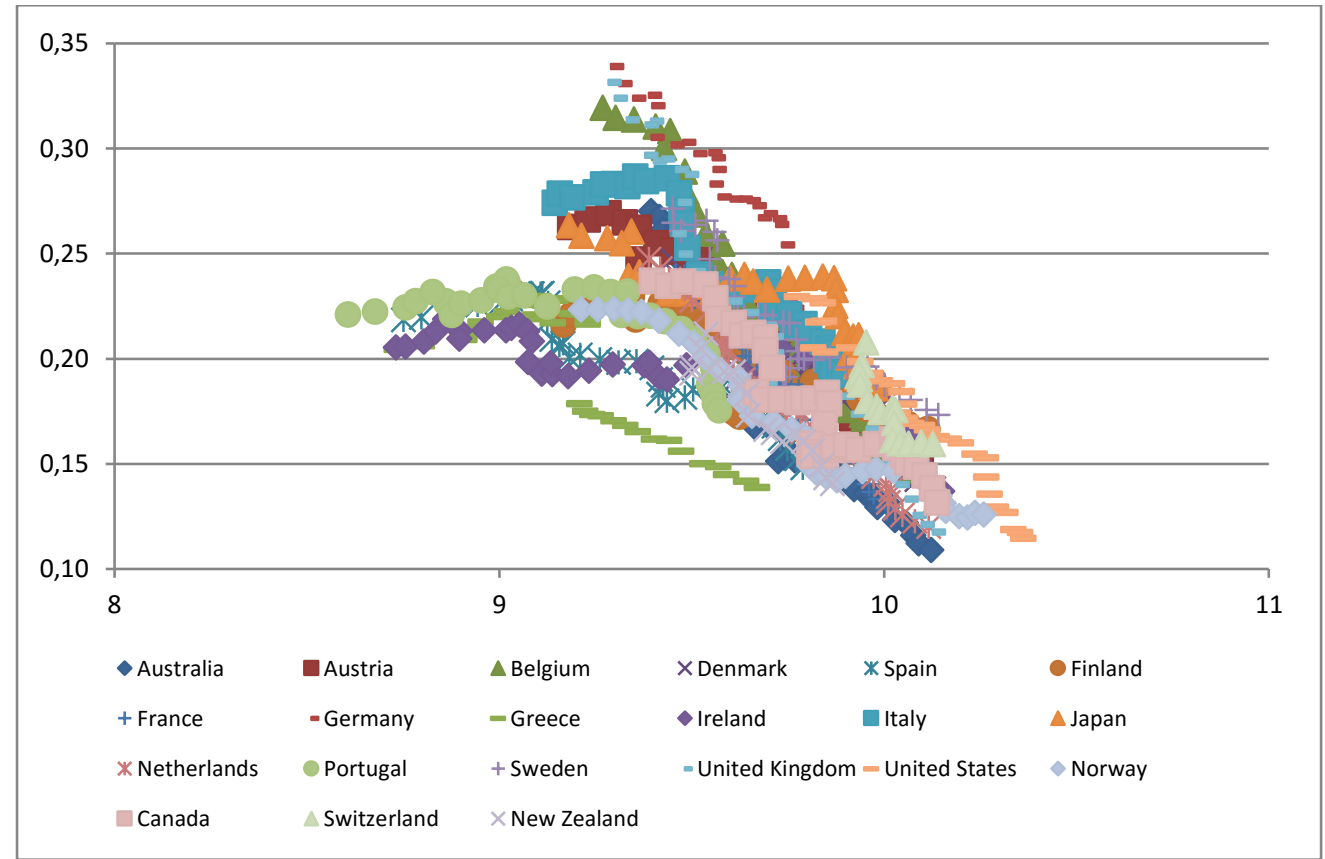

Source: EU Klems Database, STAN Database (OECD), Maddison-Project (2013 version) ${ }^{16}$

\footnotetext{
${ }^{16}$ Data on manufacturing employment share for Canada, New Zealand, Norway and Switzerland are from the STAN Database. For the other countries, data on manufacturing employment share are from the EU Klems Database.
} 
Technological heterogeneity across sectors has also long been identified as one potential driver of structural change and so deindustrialization ${ }^{17}$. In his pioneer work, Baumol (1967) early formulated the 'cost disease' hypothesis according to which economic resources, especially labor, would move from the 'dynamic' or 'progressive' sectors, those exhibiting a relatively high rate of technological progress (productivity growth), to the 'stagnant' or 'nonprogressive' sectors. Under the assumption that wages grow equally fast in all sectors (perfect mobility of labor), the unit production costs and prices increase relatively faster in the less dynamic sectors (Hartwig, 2015). In an influential paper, Ngai and Pissarides (2007) generalize Baumol's theory and provide it with stronger foundations. In particular, they derive the conditions under which unequal (exogenous) sectoral TFP growth rates can generate structural change along a balanced growth path in a multi-sector model of growth with homothetic preferences and two production factors, namely labor and capital. They notably find that structural change requires an elasticity of substitution across consumption sectors being different from one. Along the balanced growth path, labor gradually moves to the consumption sectors with a relatively low TFP growth rate provided that the elasticity of substitution between the consumption sectors is small, i.e. lesser than one. If the elasticity of substitution is greater than one, labor then progressively moves to the sectors characterized by a relatively high TFP growth rate ${ }^{18}$. In Ngai and Pissarides' model, structural change occurs as a consequence of relative price effects driven by heterogeneous sectoral productivity growth rates ${ }^{19}$. Using the EU Klems database, which provides data on employment and nominal and real value added for most European countries and some non-European countries, thus allowing the computation of both a labor productivity index and a price index (deflator), table 2 shows information on the growth of labor productivity and prices in manufacturing and services in a selected set of advanced countries over the period 1970-2007. It is noteworthy that the indicator used to measure employment is 'total hours worked', and not 'total workers' as in most previous research, which dramatically improves the accuracy of the measure of labor productivity growth.

Table 2: Average Annual Growth Rate of Labor Productivity and Prices, 1970-2007

\begin{tabular}{|l|c|c|c|c|c|c|}
\cline { 2 - 7 } \multicolumn{1}{c|}{} & \multicolumn{3}{c|}{ Labor Productivity } & \multicolumn{3}{c|}{ Prices } \\
\cline { 2 - 7 } \multicolumn{1}{c|}{} & Manufacturing & Services & Differential & Manufacturing & Services & Differential \\
\hline EU15 & $3,3 \%$ & $1,5 \%$ & $1,7 \%$ & $2,2 \%$ & $2,9 \%$ & $-0,7 \%$ \\
\hline United States & $3,5 \%$ & $1,0 \%$ & $2,5 \%$ & $2,6 \%$ & $4,5 \%$ & $-1,8 \%$ \\
\hline Australia & $2,4 \%$ & $1,3 \%$ & $1,1 \%$ & $5,4 \%$ & $6,1 \%$ & $-0,8 \%$ \\
\hline Japan & $4,9 \%$ & $2,7 \%$ & $2,2 \%$ & $0,2 \%$ & $2,6 \%$ & $-2,4 \%$ \\
\hline
\end{tabular}

Source: EU Klems Database

\footnotetext{
${ }^{17}$ As stressed by Stijepic (2011:14) the reason why technological differences exist across sectors is because the nature of the final product differs across sectors strongly. "Therefore, the (physical) production processes, the resources which are used in production, the sectoral market-structures, the degree of technology-spillovers from other sectors/industries as well as transfer-process of the final-product to the consumer differ across sectors strongly. In general, these differences affect the scope for technological innovation, rationalization (substitution of labor by capital) and division of labor for a given level of technological development."

18 In case the elasticity of substitution is equal to one, the employment shares remain constant, as well as the nominal consumption expenditure and value added shares.

${ }^{19}$ Also focusing on the supply side, other scholars have shown that it is possible to have changes in relative prices, which is the trigger mechanism of structural change in the presence of homothetic preferences, even if technical progress is neutral across sectors (see e.g. Caselli and Coleman, 2001; Acemoglu and Guerrieri, 2008).
} 
The results of table 2 are consistent with the conditions needed in Ngai and Pissarides' model for labor to move away from the manufacturing sector into services when the elasticity of substitution between manufactures and services is relatively low. The average annual growth rate of labor productivity over the period 1970- 2007 is indeed higher in manufacturing than in services in the EU15, Australia, Japan and the US, a situation also likely to explain the drop in the relative price of manufactures. As shown in appendix 4, labor productivity has risen faster in the manufacturing sector than in services in virtually all countries, with the exception of Luxembourg where the growth of labor productivity in services was spurred by the development of the financial activities. In parallel, the relative price of manufactures has decreased in virtually all countries, with the exceptions of Norway and Portugal. These exceptions suggest that the growth differential in productivity between manufacturing and services is not the only driver of the relative price of manufactures, although it is a key determinant as shown in figure 4 .

Figure 4: Scattergram Showing the Relationship between the Differential in the Average Annual Growth Rate of Labor Productivity between Manufacturing and Services (Horizontal axis) and the Differential in the Average Annual Growth Rate of Prices between Manufacturing and Services (Vertical Axis), 20 OECD countries, 1970-2007

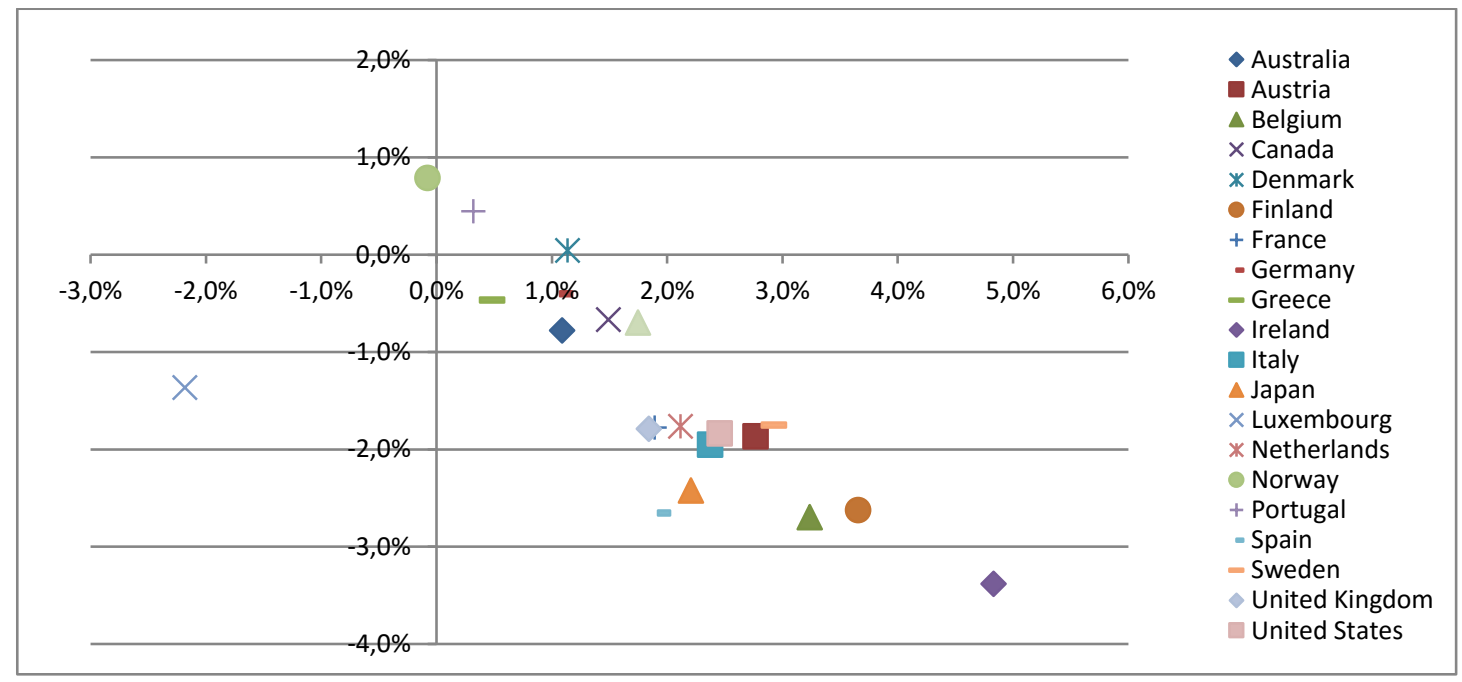

Source: EU Klems Database, STAN Database (OECD) ${ }^{20}$

The horizontal axis measures the differential in the average annual growth rate of labor productivity between manufacturing and services in a selected set of OECD countries over the period 1970-2007. The vertical axis is the differential in the average annual growth rate of prices between manufacturing and services. While figure 4 confirms that faster labor productivity growth in manufacturing has been associated with a decline in the relative price of manufactured goods in most advanced countries, it also spotlights a strong negative correlation, at a country level, between the differential in the average annual growth rate of labor productivity between manufacturing and services and the relative price inflation of manufactures.

${ }^{20}$ Data for Canada and Norway are from the STAN Database. For the other countries, data are from the EU Klems Database. 
The technological or supply-side argument, which links the process of deindustrialization with rapid productivity growth in the manufacturing sector, has been largely supported by empirical studies (see e.g. Kravis et al., 1983; Baumol, Blackman, and Wolff 1985, 1989; Rowthorn and Wells 1987; Lawrence, 1991; Krugman and Lawrence 1993; Rowthorn and Ramaswamy 1997, 1999; Rowthorn and Coutts, 2004, 2013; Ngai and Pissarides, 2004, 2007; Nickell et al., 2008; Kollmeyer, 2009; Kang and Lee, 2011; Tregenna, 2013, 2015; Cruz, 2015) ${ }^{21}$. While figure 5 confirms that the fall in the manufacturing share of national employment has occurred along with faster labor productivity growth in manufacturing $\mathrm{n}$ virtually all selected countries, it is not clear whether larger productivity growth differential between manufacturing and services has led to more deindustrialization in cross-section of countries. The latter result, which may truly appear surprising at first glance, is potentially because the relation depicted in figure 5 fails to take into account the other drivers of structural change like economic maturity and international trade. With respect to trade, figure 5 seemingly gives support to Matsuyama's (2009) view that considering the global perspective of structural change, and modelling the interdependence across countries, are essential to understand why faster technological progress in manufacturing does not necessarily translate into faster deindustrialization in cross-section of countries.

Figure 5: Scattergram Showing the Relationship between Differential in the Average Annual Growth Rate of Labor Productivity between Manufacturing and Services (Horizontal axis) and Change in the Percentage of the Labor force in Manufacturing (Vertical Axis), 20 OECD Countries, 1970-2007

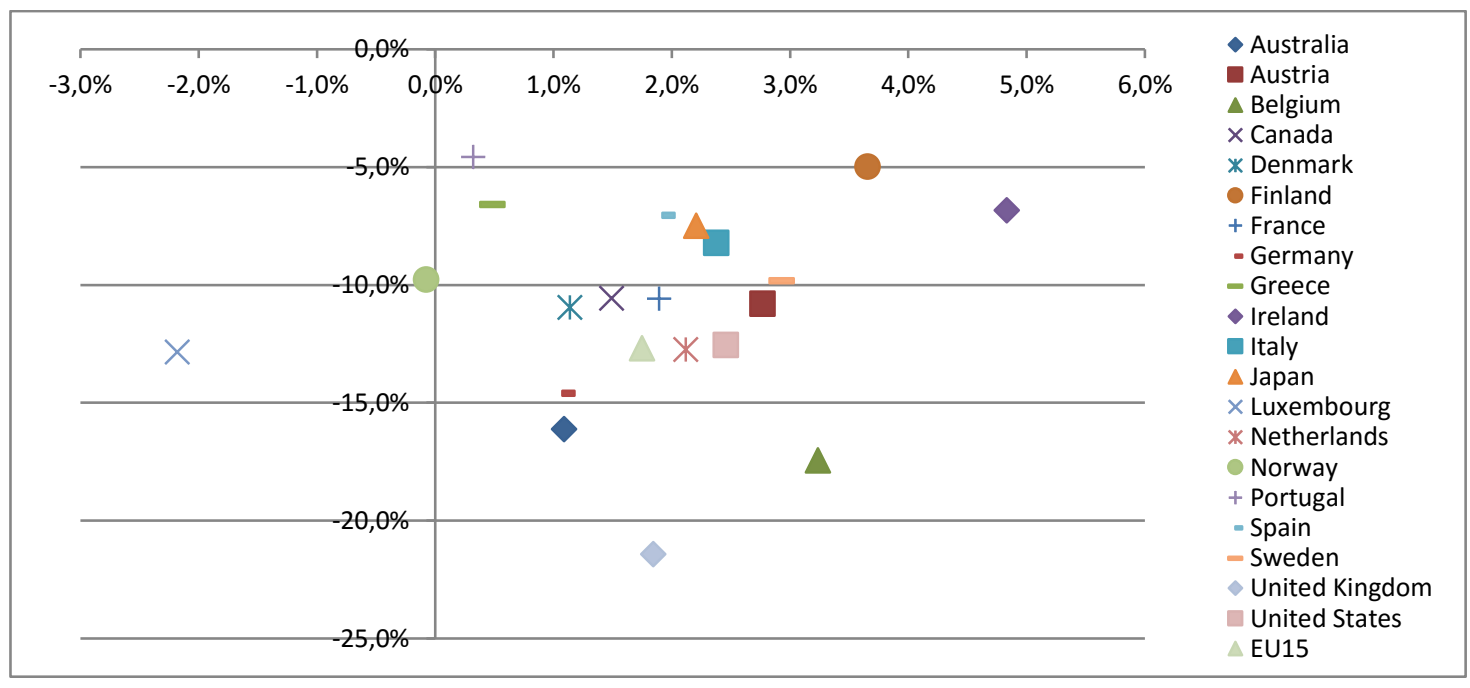

Source: EU Klems Database, STAN Database (OECD) ${ }^{22}$

A number of economists have referred to deindustrialization that arises from income and substitution or relative-price effects as 'positive' deindustrialization. Such deindustrialization, which takes place as a result of systematic changes in consumption patterns over the course of economic development and faster productivity growth in manufacturing relative to services, is labelled as 'positive' because it is viewed not as a pathological or undesirable phenomenon, but as a symptom of economic success, the natural effect of industrial dynamism (Alderson, 1999:706; Rowthorn and Ramaswamy, 1999:19).

\footnotetext{
${ }^{21}$ The technological argument has also been questioned by some scholars. See e.g. Nordhaus $(2005,2006)$

22 Data for Canada and Norway are from the STAN Database. For the other countries, data are from the EU Klems Database.
} 
While a substantial part of the literature on the causes of structural change has investigated the final demand channels - income and relative price effects - through which structural change may take place in market economies, a few studies have recently pointed out the importance of taking explicitly into account all goods and services embodied in the final products, as firms producing the final products are in turn consumer of goods and services via intermediate inputs. This research recommendatio has been motivated by empirical evidence showing that a number of services for which final demand plays only a relatively small role ${ }^{23}$, especially professional and business services, finance and real estate, have experienced a significant growth in advanced countries over the last few decades ${ }^{24}$. As documented by Berlingieri (2014), the employment share of professional and business services increased by $9.2 \%$ percentage points in the US between 1948 and 2007, contributing 40\% of total employment growth in services. With finance and real estate, these activities contributed $50 \%$ of total employment growth and $94 \%$ of total GDP growth in US services. As shown in appendix 5 and 6 , finance, real estate and professional and business services (PBS) have also dramatically grown in Europe since 1970. By way of illutsratuon, employment in those services was multiplied by around three in the EU15 between 1970 and 2007, which corresponds to an average annual growth rate of 3.1\%. By comparison, employment only grew at a rate of $0.2 \%$ in the whole economy. PBS accounted for a large part of the growth, as employment in PBS was multiplied by around four, leading to a sharp rise in the share of PBS in total employment in the EU15 from 3.4 to $12.7 \%$. According to Berlingieri (2014), a key source of the changes in the use of intermediate inputs over time, and of the real evolution of the input-output structure of advanced economies, has been 'outsourcing' or 'contracting out'. Thus, many activities such as design, catering, cleaning and transport that were previously performed in-house by manufacturing firms have been increasingly outsourced to specialized service providers, inducing a reclassification of economic activity in favor of services. This evolution has sometimes been referred to as the 'statistical artefact' or 'statistical illusion' aspect of the deindustrialization process (Tregenna, 2015). A wider definition of the manufacturing sector, which would include all the service inputs embodied in the final output of the manufacturing sector, wouldn't only increase the size of the sector but also likely reduce the extent of deindustrialization ${ }^{25}$. Figure 6 below plots the changes in the employment shares of manufacturing and finance, real estate and PBS between 1970 and 2007 for a set of selected advanced countries. It reveals, among others, that the higher the rise in the share of finance, real estate and PBS in national employment, the more deindustrialization on average.

\footnotetext{
${ }^{23}$ These services are said to exhibit a relatively high degree of "forward linkage", a measure for assessing the interconnection of a sector with the rest of the economy. See e.g. Acemoglu et al. (2012).

${ }^{24}$ Based on the early contributions of Katouzian (1970) and Singelmann (1978), the aggregate services sector is sometimes decomposed in the literature into 'distributive services' (transportation, wholesale and retail trade, etc.), 'producer services' (banking, insurance, real estate and PBS such as engineering and architectural services, accounting and bookkeeping, legal services, etc.), 'social services' (medical and health services, hospitals and education, etc.), and 'personal services' (domestic services, hotels and lodging, eating and drinking, etc.). The first two categories are traditionally considered as being related to goods production, although 'producer services' are also provided as intermediate inputs for the production of services. By contrast, the last two categories are traditionally considered as delivering final or consumer services (Schettkat and Yocarini, 2006).

${ }^{25}$ For instance, the 2013 Industrial development Report (2013) estimates through an accounting exercise that the number of manufacturing-related jobs in services worldwide amounted to 73 million in 1995, then rose to 95 million in 2009 due in part to outsourcing. These figures are found by using input-output data allowing the computation of the job-content of services that go as inputs into manufacturing.
} 
Figure 6: Scattergram Showing the Relationship between Change in the Percentage of the Labor Force in Finance, Real Estate, and PBS (Horizontal Axis) and Change in the Percentage of the Labor Force in Manufacturing (Vertical Axis), 20 OECD countries, 1970-200726

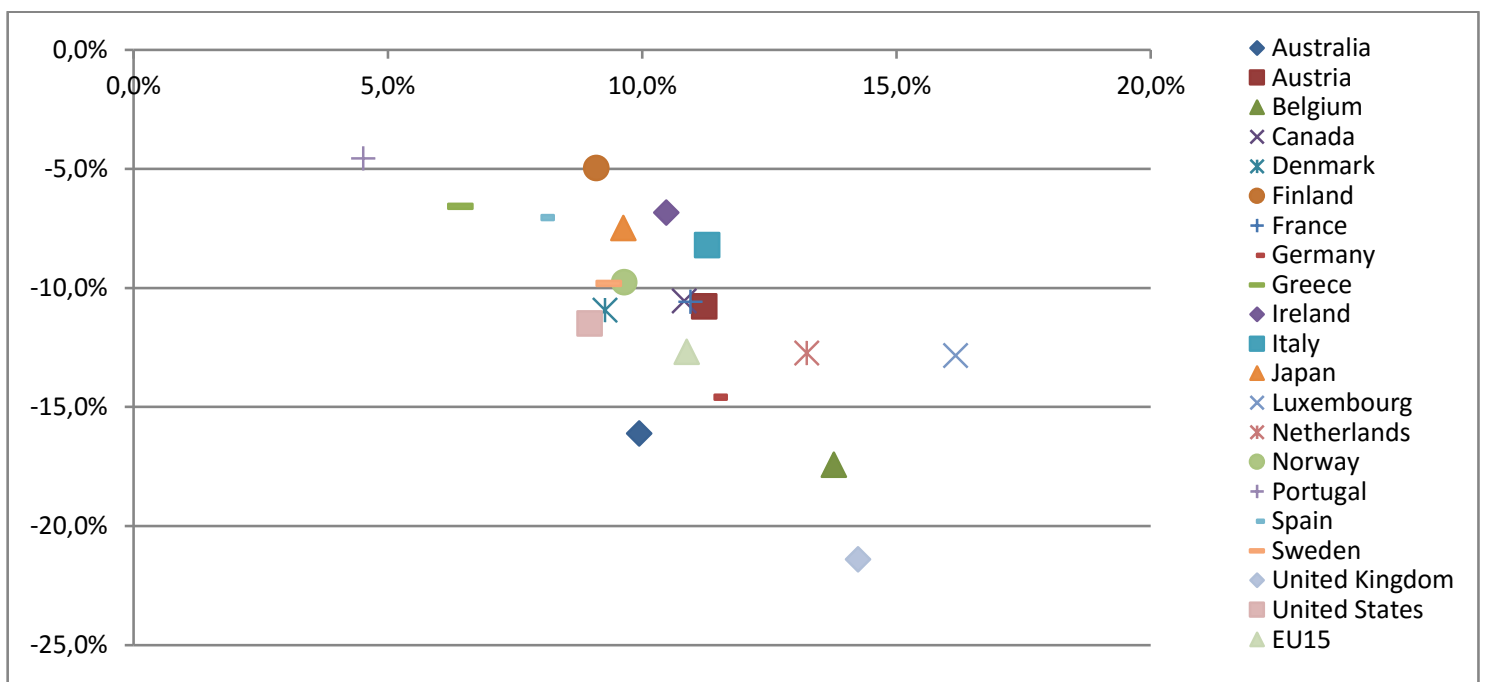

Source: EU Klems Database, STAN Database (OECD) ${ }^{27}$

Figure 6 thus suggests that the decline in manufacturing employment has been associated with the growth of services for which final demand plays only a relatively small role, especially of professional and business services. Some part of deindustrialization may then be explained by a real mutation of the production system characterized by increased outsourcing of activities away from manufacturing. Unfortunately, long-time series on internationally comparable and detailed input-output data for the advanced countries, which would allow an accounting valuation of the evolution of the manufacturing firms' externalization strategy, are missing today. As an indirect alternative measure, Demmou (2010) proposes to have a look at the evolution of the ratio of intermediate consumption over gross output in manufacturing over time. Data on intermediate consumption and gross output are available in the STAN Database and the EU Klems Database for most advanced countries. As shown in appendix 7, the share of intermediate inputs in manufacturing output grew in virtually all countries between 1970 and 2007, with truly some acceleration in the 1990s, a situation already emphasized by Demmou (2010) for the French case. In the EU15, this share rose from 0.64 to 0.66 between 1970 and 1990, and from 0.66 to 0.72 between 1990 and 2007. This evolution potentially highlights a higher division of labor in the economy, with some possible implications in terms of productive efficiency. Interestingly, figure 7 below shows in a cross-section of advanced countries that the degree of deindustrialization, i.e. the negative change in the percentage of the labor force in manufacturing, is positively correlated to the evolution of the ratio of intermediate consumption over gross output in manufacturing between 1970 and 2007. To the best of our knowledge, the hypothesis of outsourcing, seen as part of the explanation of relative manufacturing decline, has never been formally tested within an econometric framework including all identified primary sources of deindustrialization. The present study has the hope of filling this gap.

\footnotetext{
${ }^{26}$ The data for the US begin in 1977.

${ }^{27}$ Data for Canada and Norway are from the STAN Database. For the other countries, data are from the EU Klems Database.
} 
Figure 7: Scattergram of the Relationship between Change in the Ratio of Intermediate Consumption over Gross Output in Manufacturing (Horizontal Axis) and Change in the Percentage of the Labor

Force in Manufacturing (Vertical Axis), 20 OECD Countries, 1970-2007

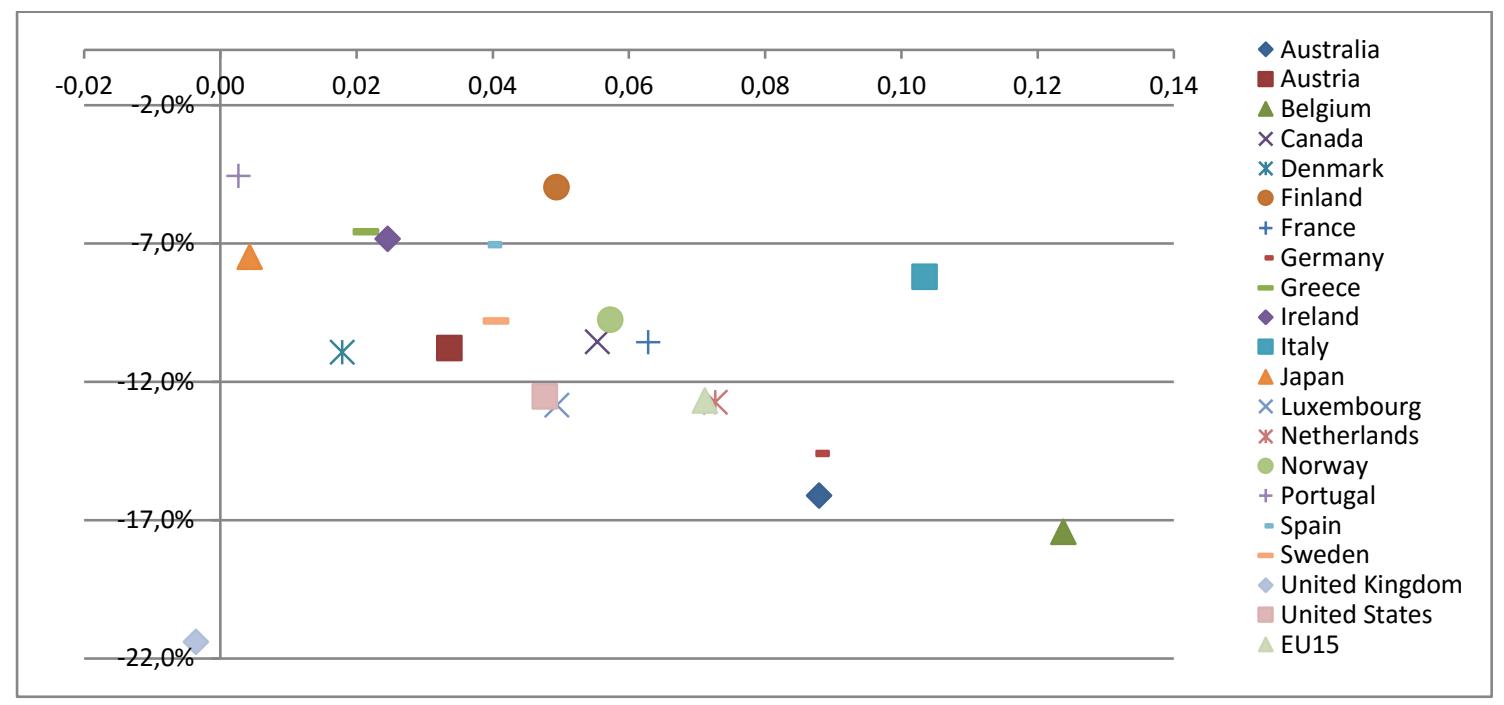

Source: EU Klems Database, STAN Database (OECD) ${ }^{28}$

In addition to outsourcing from manufacturing, Fuchs (1968) also highlights the potential effect on structural change of contracting out services that were previously produced not in the firm but in the household. While these services are indeed not valuated in national accounts when produced by the households, they officially enter the service sector when produced by the market, a situation labelled as the 'marketization of home production'. According to Fuchs (1968), contracting out services that were once produced in the household becomes more efficient as income increases (Kongsamut et al., 2001). In line with this view, a strand of the literature devoted to identifying the causes of structural change has explicitly introduced home production into analysis as a factor likely to explain some part of the labor market shift towards services (see e.g. Freeman and Schettkat, 2005; Ngai and Pissarides, 2008; Rogerson, 2008; Buera and Kaboski, 2012a and 2012b; Barany and Siegel, 2014 ${ }^{29}$ ). In parallel, a number of papers have investigated the interaction between structural change, the marketization of home production and female work to explain the evolution of gender outcomes in working hours and wages (see e.g. Ngai and Pissarides, 2008; Rendall, 2014; Ngai and Petrongolo, 2015). These papers have been motivated by a few stylized facts revealing notably a rise in female work - which took place entirely (in net terms) in the service sector - and women's relative wages, and a decline in women's working hours in the household (Ngai and Pissarides, 2008). For instance, Ngai and Petrongolo (2015) develops a model in which the growth of services, driven by structural change and the marketization of home production, acts as a gender-biased demand shift raising women's relative wages and market hours.

\footnotetext{
${ }^{28}$ Data for Canada and Norway are from the STAN Database. For the other countries, data are from the EU Klems Database. ${ }^{29}$ Barany and Siegel $(2014,2015)$ interestingly identify structural change as a driving force behind the polarization of the labor market in the US, a phenomenon characterized by the relative growth of wages and employment of high-wage occupations and low-wage occupations compared to middle-wage occupations. This account of polarization of the labor market adds to the 'routinization' hypothesis according to which the ICT substitute for middle-skill and so middle-wage (routine) occupations, whereas they complement the high-skilled and high-wage occupations (Barany and Siegel, 2015:2) (see e.g. Autor et al., 2003, 2006), Autor and Dorn (2013), Goos, et al. (2014), Michaels et al. (2014), Feng and Graetz (2015).
} 
Most theoretical models of structural change have primarily focused on the "internal" factors likely to generate structural change in one specific economy, thus implicitly considering that this economy is not interacting with the rest of the world. One crucial implication of this hypothesis is that sectoral productions must necessarily reflect the corresponding household decisions in terms of consumption and investment (Herrendorf et al., 2014). A simple look at the data of any country yet clearly reveals that such conditions are never satisfied in reality. As noted by Matsuyama (2009), "we need to keep reminding ourselves of the simple truth: we live in an interdependent global economy and our planet, the world economy, is the only closed economy we know of". Trade allows sectoral consumption and/or investment to be different from sectoral production at a country level. According to traditional trade theory, opening up the borders brings about a reallocation of economic activity across sectors within each country involved in trade. This sectoral reallocation largely takes place as a result of comparative advantage(s) driven, among others, by technology and factor endowments. Consequently, a country's economic structure is directly affected by the specialization patterns induced by trade ${ }^{30}$. In addition, trade has the potential to boost productivity, especially in the sectors exposed to foreign competition, and to spur income growth, thus affecting the sectoral expenditures shares, and hence the economic structure, through both the income and substitution effects. Matsuyama (2009) has been pioneer in studying explicitly the effects of international trade on structural change and so relative manufacturing decline. Taking into account the global perspective of structural change through a rigorous modelling of the interdependence across countries, Matsuyama (2009) has notably shown that an economy with comparatively higher productivity growth in manufacturing can temporarily know an increase in the share of labor employed in manufacturing and delay its process of deindustrialization. As an attempt to generalize Matsuyama's intuition, Uy et al. (2013) have recently developed a two-country model in which a country having or reinforcing some comparative advantage in the manufacturing sector can exhibit the hump-shape in manufacturing labor observed in the data for the currently rich countries, even if manufacturing is the most technologically dynamic sector.

Despite the relative lack, at least until recently, of a theoretical growth framework devoted to analyzing the dynamics of structural change under the more realistic assumption of open borders, the impact of international trade on manufacturing in the postwar period - which has witnessed a large boom in the volume of world exchanges, notably due to declining transport costs and invisible transaction costs in trade (Krugman, 1996) - has long been investigated in the empirical literature for different regions of the world. By way of illustration, Dodzin and Vamvakidis' (2004) estimates suggest that trade leads to industrialization, as well as to a relative decline of agriculture, in developing countries over the period 1960-2000. Providing a more nuanced picture for developing nations, Szirmai (2012) shows that some countries in both Latin America and Africa have experienced a process of premature deindustrialization since 1980, a phenomenon that can potentially have significant (large) impacts on productivity, income

\footnotetext{
${ }^{30}$ In a study linking economic integration and structural change, Imbs et al. (2012) argue that countries specialize because they integrate internationally, with their regions producing according to the global pattern of comparative advantage. In line with this view, Rowthorn and Wells (1987) went so far as to contend that a country's trade specialization was the single most important factor able to explain the differences in the employment structure of advanced countries.
} 
growth and institutions ${ }^{31}$. In parallel to industrialization of emerging countries in the second half of the $20^{\text {th }}$ century, especially in Asia (see e.g. Weiss and Tribe, 2016), the first signs of deindustrialization have been detected in advanced countries. Consequently, global integration between rich and poor countries has commonly been blamed for the relative manufacturing decline observed in advanced countries, what Krugman (1996) has called the 'deindustrialization hypothesis'. For instance, Autor et al. (2013) conclude from the main specification of their model, based on monopolistic competition and variations in industry labor productivities across countries, that rising Chinese import competition may explain one-quarter of the aggregate drop in US manufacturing employment ${ }^{32}$. Autor et al's Ricardian model interestingly shows that trade can influence the allocation of labor between the traded and non-traded sectors ${ }^{33}$ if trade is imbalanced. Given the assumptions of the model, balance trade indeed implies that the job-content of exports is exactly equal to the job-content of imports. Imbalanced trade is one way of breaking this symmetry ${ }^{34}$. Another way is to consider Heckscher-Ohlin or specific-factor models with heterogeneous sectoral production functions with regard to factor intensities. Such kind of specification indeed allows for a country's comparative advantage to be also driven by some national disparities in relative factor endowments. The job-content of exports can then be different from the job-content of imports even if trade is balanced as relative prices are not solely driven by disparities in industry labor productivities. Using input-output data on OECD countries for 1978-1995 to estimate the labor content embodied in changes in manufacturing output resulting from changing patterns of trade, Kucera and Milberg (2003) thus find that changes in foreign trade of manufactures had a significant negative net effect on manufacturing employment in all advanced countries, with the labor-intensive manufacturing sectors experiencing relatively large employment losses due to growing North-South trade ${ }^{35}$.

Trade models are particularly relevant to understand why trade leads countries to specialize in some traded sectors according to some comparative advantages(s), thus generating structural change. As shown in appendix 8 , international specialization in manufacturing has been associated with a rise in the share of imports in domestic final demand for manufactures in advanced economies, an evolution that also reflects, at least to some extent, the rising dependence of national manufacturing on trade and exports. With respect to this indicator, large differences can be observed across countries. By way of illustration, while the share of imports in domestic final demand for manufactures was around $12 \%$ in Japan in 1995 (rising to 23\% in 2011), it was around $72 \%$ in Belgium (rising to $83 \%$ in 2011) and 89\% (rising to 93\% in 2011) in Luxembourg for the same reference year. While countries truly specialize in some manufacturing sectors, Herrendorf et al. (2014) have also recently drawn attention to growing trade in services, as this trend is likely to have dramatic influence on the nature and speed of structural

\footnotetext{
${ }^{31}$ See e.g. Palma (2008 and 2014), Szirmai (2012), Imbs (2013), Rodrick (2015) and Tregenna (2015) for further evidence of premature deindustrialization in Africa and Latin America.

32 In the same vein, Pierce and Schott (2014) find a link between the sharp decline in US manufacturing employment beginning in 2001 and a change in US trade policy that eliminated potential tariff increases on Chinese imports.

33 In the literature on trade, traded sectors often restrictively refer to the manufacturing sectors, while non-traded sectors typically refer to services.

${ }^{34}$ See e.g. Craighead and Hineline (2015) for a study examining the compositional changes (structural change) that occur in both developing and developed countries experiencing current account reversals, defined as large and persistent decreases in current account deficits, using sectoral-level data on output and employment growth.

35 In the same vein, Wood $(1994,1995)$ finds that international trade reduced the demand for unskilled labor in advanced countries between 1970 and 1990 .
} 
change and deindustrialization in countries like the US that seem to have a comparative advantage in certain tradable services.

In addition to sectoral specialization induced by trade, it is noteworthy that foreign competition leads global firms, and especially manufacturing firms, to seek continuous improvement. Global firms indeed have strong incentives to increase their degree of competitiveness on world markets. And this can be achieved through different channels. For instance, global firms may invest in research and innovation activities, modify their production processes, and especially the ratio of labor to capital, and reorganize themselves at a world scale. Due to declining trade costs and the progress in ICT, offshoring - defined as the relocation abroad of a company business process (to unaffiliated firms or to own affiliates) - has thus become increasingly profitable over the last decades, contributing to larger volume of $\operatorname{trade}^{36}$ and higher degree of international fragmentation of the production ${ }^{37}$. Offshoring, which allows global firms to enhance the division of labor and simultaneously reap the benefits associated with the comparative advantage(s) of different countries, can involve not only supporting processes, such as accounting and administrative tasks $\mathrm{s}^{38}$, but also operational processes, such as manufacturing, with some potentially significant implications in terms of deindustrialization in advanced countries. While offshoring has very often been considered fearfully as a major threat to manufacturing jobs and associated with massive unemployment in advanced countries, thus explaining why the topic has been particularly prominent in the political and scientific debate, a number of scholars have tended to qualify this pessimistic view, contending that offshoring can generate significant efficiency gains and enhance productivity growth ${ }^{39}$, especially when low-productivity-growth activities are offshored (see e.g. Stijepic and Wagner, 2008; Stijepic, 2011). Robert-Nicoud (2008:518) moreover argues that offshoring, and so the specialization by function rather than by sector, relaxes the pressure to move abroad, notably to low-wage countries, the entire manufacturing production chain, thus helping to retain the core activities in manufacturing, the 'complex tasks' like design, R\&D and post-production activities in advanced countries ${ }^{40}$.

A number of econometric studies have attempted to quantify the relative importance of globalization or 'external' factors on deindustrialization in advanced countries (see e.g. Rowthorn and Ramaswamy, 1997, 1999; Alderson, 1997, 1999; Gaston, 1998; Rowthorn and Coutts, 2004; Brady and Denniston, 2006; Kollmeyer, 2009; Kang and Lee, 2011; Rowthorn and Coutts, 2013). While these studies find a significant negative effect of globalization on relative manufacturing employment, they largely suggest that internal factors were quantitatively more important in accounting for deindustrialization. Given

\footnotetext{
${ }^{36}$ Offshoring has been one of the most rapidly growing components of trade (Grossman and Helpman, 2005; Blinder, 2007). 37 Through an empirical exercise aiming at slicing up the global value chains, Timmer et al. (2014) document that international fragmentation, as measured by the foreign value-added content of production, has rapidly increased since the early 1990 s.

${ }^{38}$ The term 'offshore outsourcing' is often used to refer to outsourcing abroad of service-type activities supporting production that were previously performed in the manufacturing firm (see Manning et al., 2008).

${ }^{39}$ See e.g. Bhagwati et al., 2004; Samuelson et al., 2004, Amiti and Konings, 2007; Kasahara and Rodrigue, 2008; RobertNicoud, 2008; Amit and Wei, 2009; Goldberg et al., 2010; Stijepic and Wagner, 2012

40 Using recent data on foreign direct investment (FDI), a number of studies have attempted to assess the impact of offshoring and relocation on manufacturing employment in advanced countries (see e.g. Marin, 2004; Brady and Denniston, 2006, Kang and Lee, 2011). More generally, the use of data on FDI, which is sometimes split into defensive and expansionary types (see e.g. Chen and Chen, 1995), has recently gained in importance in deindustrialization studies, especially as the global landscape of FDI has shifted to the developing and emerging world. As noted by Kudina and Pitelis (2014), who provide strong empirical support for a relationship between FDI inflows into developing and emerging economies and deindustrialization of developed economies, FDI inflows into developing world exceeded that to the developed economies for the first time in 2010.
} 
the lack of readily available data and the difficulty to empirically identify and measure all the different channels through which globalization may influence structural change, these studies typically use data on trade flows in manufactures, both imports and exports, as a proxy to examine the broad impact of globalization on relative manufacturing employment. Besides the growing penetration of developing nations in world exchanges, the trade argument has been empirically funded on a severe deterioration of the trade balance in manufactures in a number of advanced countries, especially in the US and the UK. As shown in figure 8 below, the US and the UK, which have experienced a relatively high degree of deindustrialization, rank amongst the countries where the ratio of exports to imports in manufactures has declined the most ${ }^{41}$.

Figure 8: Scattergram of the Relationship between Absolute Change in the Ratio of Manufactures Exports over Manufactures Imports (Horizontal Axis) and Change in the Percentage of the Labor Force in Manufacturing (Vertical Axis), 18 OECD Countries, 1970-2007

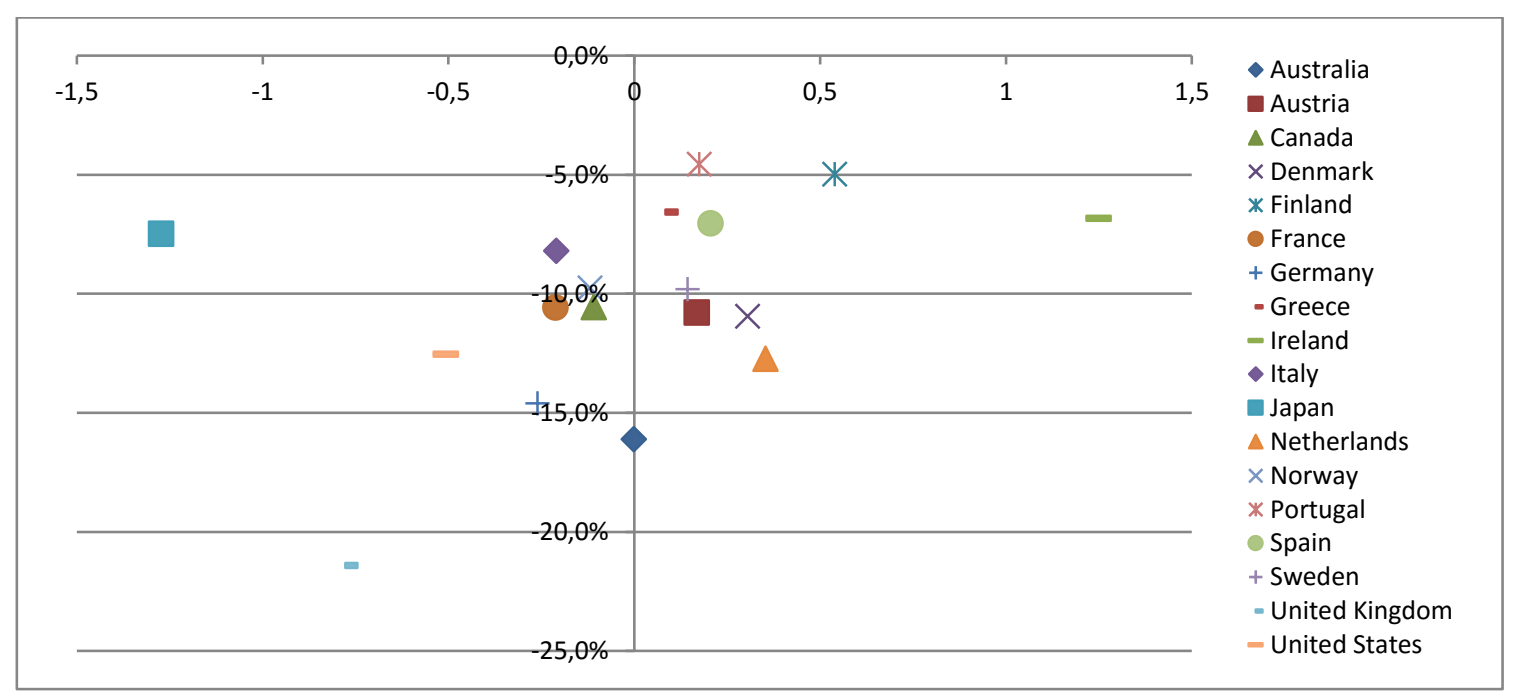

Source: OECD's International Trade by Commodities Database

\section{Description of the data and empirical methodology}

\section{Description of the data}

The dependent variable measures the share of a country's workforce employed in the manufacturing sector. Computed by use of the indicator "total hours worked", and not "total persons engaged", this variable captures the extent to which deindustrialization has taken place in advanced countries since the 1970s. By contrast with most previous empirical studies, this variable is log-transformed to allow

\footnotetext{
${ }^{41}$ While Japan has also known a large drop in the ratio of exports to imports in manufactures, it is noteworthy that, contrary to the US and the UK, the Japanese trade balance in manufactures is still largely positive in 2007.
} 
for a potentially non-linear but monotonic relationship between relative manufacturing employment and the explanatory variables. In addition to a seemingly better fit of the data, this choice is motivated upstream by the limited value range of the dependent variable. As the share of a country's workforce in manufacturing is comprised between 0 and 1 , one can reasonably expect the marginal effect of any explanatory variable to be not constant in the different estimated models. Under the assumption that no one factor could never completely deindustrialize a country, the absence of transformation of the dependent variable may lead to overestimate the impact of the factors that have early contributed to deindustrialization in advanced countries compared to the factors that really started operating when the share of manufacturing in total labour force had already declined. By way of illustration, trade is usually believed to have begun affecting relative manufacturing employment later than internal factors like economic maturity and unbalanced productivity growth. Data on employment at industry-level are derived from the EU Klems database (ISIC Rev.3) for all countries except Canada and Norway. For these two countries, data are retrieved from the OECD's STAN (structural analysis) database (ISIC Rev.3).

The key explanatory variables are designed to capture the four primary sources of deindustrialization highlighted in the theoretical literature. The first explanatory variable measures a country's log of gross domestic product per capita expressed in 1990 international dollars as reported by Maddison (2013). In order to allow for a non-monotonous impact of real income on a country's share of manufacturing in total employment, and thus to test the hump-shaped relationship between relative manufacturing employment and economic maturity suggested by figure 3 , we include a squared term for this variable in the different regressions.

The second explanatory variable aims at capturing the effects of cross-sector heterogeneity in labor productivity growth on relative manufacturing employment. It measures the log of the ratio of labor productivity in manufacturing over labor productivity in services. Labor productivity in manufacturing and services is computed using data on sectoral employment and real value added from the EU Klems database (ISIC Rev.3) and the OECD's STAN (structural analysis) database (ISIC Rev.3). The indicator of employment is "total hours worked", and not "total persons engaged", which dramatically improves the accuracy of the labor productivity measure. Provided that the elasticity of substitution between manufactured goods and services is relatively low, this second variable is expected to affect negatively a country's share of manufacturing in total employment.

The third explanatory variable is related to outsourcing. In the absence of accurate and reliable data on this phenomenon, outsourcing of services from the manufacturing sector is measured indirectly, as it has been suggested by Demmou (2010), by looking at the evolution of the ratio of intermediates to gross output in the manufacturing sector. Sectoral-level data on intermediate consumption and gross output are available in the EU Klems database (ISIC Rev.3) and the OECD's STAN (structural analysis) database (ISIC Rev.3). 
The fourth set of explanatory variables is intended to measure the broad impact of international trade in manufactures on relative manufacturing employment. While many empirical studies have resorted to statistics on trade balance in manufactures to investigate the effects of trade on a country's share of manufacturing in total employment, we follow the approach adopted by scholars like Saeger (1997) and Kollmeyer (2009) by disaggregating gross trade flows into imports and exports for the North and South. This choice allows for North-South global integration to be linked to deindustrialization even if North-South trade is roughly balanced, as there is strong evidence that traded manufactures between the North and South are of different factor intensities. One therefore expects the coefficient on gross imports from the South to be significantly larger in absolute value (and of opposite sign) compared to the coefficient on gross exports to the South. Data on trade flows are from the OECD's International Trade by Commodity Statistics (ITCS) database which categorizes all of the world's countries into six geographic regions, i.e. Africa, Asia, Central and South America, Europe, North America and Oceania. In line with recent Kollmeyer (2009)'s study, the South is here defined as Africa, Asia, Central and South America, and Oceania. The North covers Europe and North America. Some adjustments are made to these broad regional categories by moving Mexico (North America) and Turkey (Europe) to the South, and by moving Australia and New Zealand (Oceania) and Israel, Japan, and South Korea (Asia) to the North. Consistent with Wood $(1994,1995)$ 's influential work, trade in manufactures is defined as gross imports or exports in SITC (Standard International Trade Classification) sections 5 to 8. For international comparison purposes, the values of imports and exports are usually expressed as a percentage of total GDP. By contrast with previous deindustrialization studies, we decide to express imports and exports as a percentage of gross output in the manufacturing sector, and not of total GDP, for all countries. It appears to us that this new variable is better suited for capturing the effects of trade in manufactured goods on relative manufacturing employment. Indeed, the ratio of imports or exports in manufactures to total GDP is likely to move even if the economic situation of the manufacturing sector, assessed in terms of real production and trade, does not evolve over time, as GDP also includes the production of services. Conversely, this ratio may theoretically stay constant even if the situation of manufacturing dramatically changes over time. It may even be the case that the two ratios, i.e. the ratio of imports or exports to total GDP and the ratio of imports or exports to total gross output in manufacturing, move in opposite directions. By way of illustration, the ratio of total imports in manufactures to total GDP in Norway dropped from $21 \%$ to $16 \%$ between 1970 and 2007, while the ratio of imports in manufactures to total gross output in manufacturing rose from $37 \%$ to $48 \%$ over the same period. As manufacturing activity is affected by a number of factors, both internal and external factors, the effect of trade should logically be considered, for any given year, regarding the current activity of the manufacturing sector. It is also noteworthy that trade flows in manufactures are typically measured in gross terms in most macro datasets. While recent efforts have been made to better take into account the rising countries' specialization in global value chains (GVCs) and derive statistics on trade in value added terms ${ }^{42}$, all the long historical time series of economic indicators on trade are still expressed in gross terms. That's the reason why, for consistency purposes, we choose to express exports and imports in manufactures as a percentage of gross output, ant not value added, in manufacturing.

\footnotetext{
42 Thus, the 2015 edition of the TiVA (Trade in Value Added) database provides a number of trade indicators for 61 countries covering OECD, EU28, G20, most East and South-east Asian countries and a set of South American countries. The industry list covers 34 unique industrial sectors, including 16 manufacturing and 14 services sectors. The years covered are 1995, 2000, 2005 and 2008 to 2011.
} 
A fifth set of explanatory variables report the annual flows, the inflows and outflows, of foreign direct investment (FDI). While FDI inflows are expected to support domestic manufacturing employment, FDI outflows are contrastingly expected to reduce the demand of labour in home manufacturing, especially when FDI outflows are of defensive type, i.e. intended to restore some degree of competitiveness of home manufacturing in a global environment. Statistics onFDI flows in manufacturing should ideally be used. Unfortunately, sectoral-level data on FDI flows for advanced countries only begin in 1985 and are very incomplete. Therefore, this study uses data on total FDI flows. For international comparison purposes, FDI flows are taken as a percentage of total GDP. Data come from the OECD International Direct Investment by Industrial Sector Database.

Finally, a set of control variables is also included into the regressions. Following previous research, two first control variables are considered. The first one, i.e. the log of unemployment rate, aims at capturing what Rowthorn and Wells (1987) called the 'failure effect' or 'negative deindustrialization'. According to this argument, deindustrialization may also takes place as a result of a large and persistent structural disequilibrium in the macroeconomy, which is manifested in the poor performance in manufacturing and the overall economy. As part of this vicious circle, the labor shed by negative deindustrialization is not absorbed by the broad service sector, contributing to a rise in the unemployment rates and the share of services in total workforce. The second control variable measures the log of gross domestic fixed capital formation as a share of total GDP. As stressed by Rowthorn and Ramaswamy $(1997,1999)$, the rationale for using this variable is that capital investment is relatively focused on manufacturing, that is to say manufacturing intensive. A third control variable, i.e. the log of the participation rate for women aged between 15 and 64, is also injected into the different regression models. This variable is introduced as a proxy for the women's working hours in the household to capture the effects of the marketization of home production on structural change. As documented by a number of scholars for the US, there is a strong negative correlation between female work and women's working hours in the household (see e.g. Ngai and Petrongolo, 2015 and Olivetti and Petrongolo, 2016).

\section{Empirical methodology}

In order to study the factors that are associated with deindustrialization, defined as the decline in the share of manufacturing in total employment, we use panel data for 20 OECD countries ${ }^{43}$ from 1977 to 2007. Our sample thus contains a maximum of 620 separate observations, although some observations are missing data for some explanatory variables ${ }^{44}$. Panel data, which include the reporting of individual (countries in this case) and temporal variations, allow for richer econometric specifications than crosssectional or time series data and have the potential to greatly improve the power of statistical models. While the pooled specifications can be interesting to investigate the role of various factors in shaping differences in the sectoral structure of employment across advanced countries (see e.g. Rowthorn and

\footnotetext{
${ }^{43}$ These 20 countries include Australia, Austria, Belgium, Canada, Denmark, Finland, France, Germany, Greece, Ireland, Italy, Japan, Luxembourg, Netherlands, Norway, Portugal, Spain, Sweden, the UK and the US.

${ }^{44}$ Data on trade in manufactures are largely missing for Belgium and Luxembourg before the 2000s. These two countries are so removed from the regressions including the variables on trade. In the same vein, data on FDI are largely missing for Greece and Ireland. These two countries are then removed from the regressions including FDI variables.
} 
Wells, 1987; Saeger, 1997; Rowthorn and Ramaswamy 1999, Alderson, 1999), error components panel models controlling for persistent and time invariant country-specific effects, and thus dealing with the heterogeneity bias that can seriously affect pooled OLS estimates when the observations for particular units are structurally related to one another, is better suited to analyze the factors associated with the process of deindustrialization. The fixed-effects model (FEM) and random-effects model (REM) are the two dominant approaches for estimating the error components panel specification. Based on a BreushPagan Lagrange multiplier test for random effects, with the null hypothesis being that variances across entities is zero, and an $\mathrm{F}$ test of the heterogeneity of the individual component in a fixed-effects model, the homogeneity assumption, i.e. the assumption of no panel effect, is rejected at conventional levels of significance. A panel data specification including country-specific effects is therefore preferred.

The choice between fixed or random effects models typically depends on the properties of the error components, especially of whether or not the individual component is independent of the explanatory variables. If the individual component is correlated with the regressors, it is usual to treat the individual effects as an additional set of parameters to be jointly estimated with the other coefficients of interest, a situation termed fixed-effects. The fixed-effects (FE) estimator, also called the within estimator, then provides consistent estimates for the model's parameters. By contrast, if the individual component is assumed to be random and uncorrelated with the regressors, a situation termed random-effects, it is more efficient to apply some form of feasible generalized least square (FGLS) estimator. As noted by Judson and Owen (1999), the fixed-effects model has become a common choice for macroeconomists as it generally proves to be more appropriate than a random-effects model for many macro datasets for at least two reasons. First, the typical macro panel contains most of the countries of interest, and so does not only cover data representing a random sample from a much larger population of countries. Our study clarly includes most economically advanced countries. Second, if the individual component truly captures time-invariant omitted variables, it is very likely that unit-specific effects are correlated with one or more of the model's regressors. This can be tested by performing a Hausman test. Such a test fails to indicate that the individual effects are uncorrelated with the model's regressors. For these two reasons, we use a fixed-effects model. In line with most previous research, we add time-specific, group-invariant effects in the specification to account for unmeasured effects occurring across time but being constant across groups (countries), thus ending up with a two-way fixed-effects model. The inclusion of time dummies in the model is validated by a formal $\mathrm{F}$ test rejecting the null at conventional levels of significance that the coefficients for all years are jointly equal to zero. A number of additional tests are performed to investigate some potential complications arising from the use of panel data. These tests reveal the presence of spatial correlation or cross-sectional dependence, serial correlation, and group-wise heteroskedasticity ${ }^{45}$. To deal with these complications, we estimate the two-way fixedeffects model by means of two different procedures, namely 'feasible generalized least squares' (FGLS) and 'panel-corrected standard error' (PCSE). The PCSE procedure is actually an alternative to FGLS for fitting linear panel models when the disturbances are not assumed to be independent and identically distributed. While the FGLS estimator is more efficient if the assumed covariance structure is correct, Beck and Katz (1995) have nonetheless drawn attention towards the FGLS procedure, notably showing

\footnotetext{
${ }^{45}$ The Pesaran's test of spatial correlation rejects the null of cross-sectional independence across countries at the $1 \%$ level of significance, thus suggesting that the residuals in the specified model are contemporaneously dependent across panels. The Wooldridge test for first-order autocorrelation rejects the null of no serially correlated errors at the $1 \%$ level of significance. A modified Wald test for groupwise heteroskedasticity rejects the null of homoscedasticity at the $1 \%$ level of significance.
} 
that the full FGLS variance-covariance estimates are typically unacceptably optimistic in the presence of the type of data analyzed by most social scientists $-10-20$ panels with $10-40$ periods per panel.

We then extend the two-way fixed-effects model to explicitly include some temporal dependency into the analysis. There is a range of ways to add dynamics to the static equation ${ }^{46}$. In our study, we choose to include some $\operatorname{lag}(\mathrm{s})$ of the dependent variable as explanatory variable(s) into the regression. To the best of our knowledge, this kind of specification, which controls for the dynamics of the investigated process without treating them as a nuisance, has never been considered in the empirical literature on structural change. Generally speaking, the dynamic methods allow for the model to capture a potential dynamic effect of the explanatory variables on the dependent variable. While static panel implicitly makes the assumption that all explanatory variables have an instantaneous and only instantaneous impact, dynamic panel is indeed modelling a partial adjustment process that allows for adjustments to changes in the explanatory variables after the current period. As emphasized by Arellano (2003), the partial adjustment based approach, whose examples notably include the partial adjustment models of firm investment or labor demand, is especially relevant in the presence of adjustment costs and inertia. These adjustment costs can take a myriad of forms. In our study on deindustrialization, the adjustment costs might for instance come from the rigidities in the labor market. It is well known that employment, and so relative manufacturing employment, reacts with a delay to shifting macroeconomic conditions. The adjustment costs might also come from the force of habit in private consumption expenditures. The households indeed do not adjust instantaneously their consumption to changes in income. When considering a 'lagged dependent variable' (LDV) model, the standard estimators for static panel (with fixed individual effects), including the least squares dummy variables (LSDV) estimator, can be shown to be inconsistent, thus generating biased estimates, because this dynamic specification raises some endogeneity issue (Nickell, 1981). To address this issue, a number of consistent instrumental variables (IV) and generalized method of moments (GMM) estimators have been proposed as alternatives in the economic literature (see e.g. Anderson and Hsiao, 1981, 1982; Arellano and Bond, 1991; Arellano and Bover, 1995; Blundell and Bond, 1998, 2000). All these estimators rely upon transforming the initial model in first differences in order to eliminate the unobserved individual heterogeneity, then using one or more lag(s) of the dependent variable as internal instrument(s) for the differenced one-time lagged dependent variable. A weakness of IV and GMM estimators is that their properties hold when the number of cross-sectional units is sufficiently large, so they can be severely biased in panel data with a small number of cross-sectional units, a situation encountered in many macro panels (Bruno, 2005a). In line with this result, Judson and Owen (1999) conclude from Monte Carlo simulations that the Kiviet's (1995) bias-corrected LSDV (LSDVC) estimator should be preferred when the number of cross-sectional units is relatively small. In case the corrected LSDV is not practical ${ }^{47}$, Judson and Owen then recommend using the simpler LSDV when the number of time periods is sufficiently large, as the bias generated by the LSDV estimator substantially declines with time dimension. Moreover, using an RMSE criterion, the LSDV estimator proves to perform just as well or better than many alternatives when the number of time periods is sufficiently large. With regard to this performance, Beck and Katz (2011) argue in favor of the simpler and more flexible LSDV for long time-series-cross-section data, and

\footnotetext{
${ }^{46}$ Since the dynamics inherent in the initial model with serially correlated errors are treated as a nuisance leading to some estimation difficulties, we refer to the initial setup as the 'static model'.

47 For instance, the LSDV estimator was initially not suitable for unbalanced panel data. Extending the results by Kiviet (1995, 1999) and Bun and Kiviet (2003), Bruno (2005b) later filled in this gap.
} 
this independently from the practicability of the LSDVC estimator, as there are real costs in using the Kiviet correction, not the least of which is that standard errors will need to be calculated by some sort of block bootstrap. Following this recommendation, we estimate our dynamic specification with both FGLS and PCSE, taking into account the complications arising from the use of panel data.

As part of the methodological discussion, one also needs to tackle the issue of non-stationarity in timeseries-cross-section data. The analysis of non-stationary series has been very prominent in time series econometrics during the last three decades following the seminal and pioneering work of Engle and Granger (1987). It is therefore legitimate to wonder about the implications of non-stationary series for panel data, especially as political economy data, which is typically observed for relatively short periods of time (20-40 years), often appear to be integrated of order one, I(1), when resorting to traditional tests ${ }^{48}$. These series are said to exhibit a unit root, which means that shocks to these series accumulate forever. In the presence of integrated series, time series econometrics has long cautioned against the risks of a spurious regression as the least squares estimator will have a non-zero probability limit as $\mathrm{T}$ goes to infinity even in the extreme case of independent random walks. Fortunately, as shown by Kao (1999), the problem of spurious regression can be avoided by using panel data as the least squares estimator, applied on demeaned data, consistently estimates the true value of the parameters (Smith, 2001; Smith and Fuertes, 2016). The FE estimator can also be shown to provide consistent estimates of what Phillips and Moon (1999 and 2000) called the "long-run average rergression coefficients" when the dependent variable and the explanatory variables are significantly related to each other, no matter whether or not the disturbance process is stationary. With respect to this point, it may be the case that equilibrium or arbitrage conditions imply that certain linear combinations of integrated (of order one) variables are stationary. The disturbance process is then stationary and the variables are said to be cointegrated. As suggested by Kao (1999) and Pedroni $(1995,1999)$, we perform a Dickey-Fuller test of cointegration to check whether the disturbance process is stationary in our static model. This test reveals that the errors are stationary. Additional tests based on an Error-Correction-Model approach, i.e. those suggested by Westerlund (2007) and Gengenbach et al (2009), lead to the same conclusion. In these conditions, the FE estimator can be shown to estimate consistently the hypothetized single cointegrating vector (see e.g. Smith, 2001; Smith and Fuertes, 2016). Following Beck and Katz's (2011) guidance, we also check wether the error process is stationary in our dynamic model. As it is the case, the dynamic methods described in the previous section can be used, especially as our study's modeling issue is not at all about the univariate properties of any time-series, but the properties of the stochastic process that generated the y's conditional on the observed covariates (that is, the error process) ${ }^{49}$.

\footnotetext{
48 Performing a number of Fisher tests for panel unit root using augmented Dickey-Fuller tests, all the variables of our model, i.e. the dependent variable and explanatory variables, appear to be integrated of order one. Their first difference is stationary.

${ }^{49}$ As part of a rich discussion on the implications of non-stationarity in political economy data, Beck and Katz (2011) caution against jumping too quickly to any formal conclusion on the stationarity of any political economy series as political economy data is typically observed annually for relatively short periods of time (often $20-40$ years). Thus, while the series may be very persistent, we have no idea if a longer time period would show the series to be stationary or non-stationary. Moreover, Beck and Katz (2011) argue that many political economy series that are shown to have a unit root based on traditional stationarity tests are not likely to exhibit the characteristics of I(1) series. Let's take the example of relative manufacturing employment. As emphasized by Beck and Katz, if this series had a unit root, there would be tendency for it to wander far from its means and the variance of the observations would grow larger and larger over time. But by definition the country's share of manufacturing in total workforce is bounded between zero and hundred per cent, which then bounds how large its variance can become. Further, if the series was I(1), then we would be equally likely to see an increase or decrease in the variable regardless of its present value. Is this the right characterization of this series?
} 
Another source of inconsistent and potentially misleading results comes from the "heterogeneity bias" when one incorrectly makes the assumption of homogeneity of the slope parameters across countries (see e.g. Pesaran and Smith, 1995; Pesaran et al., 1997, 1999; Phillips and Moon, 2000; Im et al., 2003). A few techniques have been developed to estimate nonstationary panels in which the parameters are heterogeneous across groups. Two commonly used methods are the mean-group (MG) and pooled mean-group (PMG) estimators. The MG estimator (see Pesaran and Smith, 1995) relies on estimating $\mathrm{N}$ time-series regressions and averaging the coefficients, whereas the PMG estimator (see Pesaran et al., 1997 and 1999) relies on a combination of pooling and averaging of coefficients (Blackburn III and Frank, 2007). In both cases, the estimated model is an error correction model (ECM) derived from the reparametrization of an autoregressive distributive lag (ARDL) dynamic panel model, of which the AR1 and LDV specifications are special cases (see Beck and Katz, 2011). While both MG and PMG estimators allow the intercept, short-run coefficients, and error variances to differ across all panels, only the MG estimator allows the long run coefficients to be different. If the true model is heterogeneous, then the estimates obtained with the PMG estimator are inconsistent; the MG estimates are consistent in either case. As pointed out by Blackburn III and Frank (2007), the test of difference in these models can be performed with the familiar Hausman test. Such a test fails to reject the null hypothesis of systematic difference in coefficients. As a result, we conclude that the PMG estimator, which is efficient under the null hypothesis, is preferred. We perform another Hausman test to compare the MG estimator with the dynamic fixed-effect estimator, the latter restricting the long-run coefficients of the cointegrating vector to be equal across all panels, as well as the speed of adjustment coefficient and the short-run coefficients, while allowing panel-specific intercepts. Results indicate that the FE model is preferred over the MG model.

\section{Empirical Results}

The regression results are shown in table $3^{50}$. While models 1 to 6 refer to the static analysis, model 7 refers to the dynamic specification including one lag of the dependent variable, namely the share of a country's labour force employed in the manufacturing sector. Model 1 isolates the effects of national affluence (GDP per capita) and unbalanced sectoral productivity growth (ratio of labor productivity in manufacturing over labor productivity in services). Model 2 also incorporates the explanatory variable intended to capture the effects of outsourcing on relative manufacturing employment, i.e. the ratio of intermediates to gross output in the manufacturing sector. Both models confirm a number of results delivered by previous research. They notably confirm the curvilinear, inverted U-shaped relationship between income per capita and relative manufacturing employment, and the negative relationship between relative apparent labor productivity in the manufacturing sector and relative manufacturing employment. Although the coefficient has the expected negative sign, model 2 fails to find a significant effect of the ratio of intermediates to total gross output in manufacturing on relative manufacturing employment, suggesting that this variable does not accurately capture the effects of outsourcing, i.e. the contracting-out of services previously produced in the manufacturing firm, on deindustrialization. Interestingly, this variable appears to be significant when using the FGSL procedure instead of the PCSE

\footnotetext{
${ }^{50}$ For simplicity purposes, only the results obtained with the PCSE procedure are presented in table 3.
} 
procedure. This result seemingly supports Beck and Katz (1995)'s findings that the FGLS procedure may produce too optimistic estimates when applied on typical political economy time-series cross-section data - 10-20 units with 10-40 periods per unit. Regarding the first control variable, i.e. unemployment, the coefficient is correctly signed in view of the "negative deindustrialization" thesis but not significant. The coefficient of the second control variable, i.e. the intensity of gross fixed capital formation, is also unsignificant. By contrast, the third control variable, i.e. the labor market participation rate of women, influences significantly (and negatively) relative manufacturing employment, thus confirming to some extent that the entire (net) rise in women's hours has taken place in the broad service sector.

Models 3 to 6 include the explanatory variables designed to capture the broad effect of globalization on relative manufacturing employment. These variables relate to trade in manufactures with the North and South and foreign direct investment (FDI). While the trade variables are expressed as a share of total GDP in model 3 and 4, they are taken as a share of total gross output in the manufacturing sector in model 5 and 6 . As expected, the results look very different according to the variables that are used to measure the effects of trade on deindustrialization. In models 3 and 4 , the coefficients of the trade variables, although they exhibit the expected sign, are unsignificant, a result that highly contrasts with previous empirical research. While this result could be due to the choice of a slightly different period of investigation ${ }^{51}$, we argue rather that it is because of an inaccurate definition of the trade variables. In model 5, the coefficients of the trade variables all appear highly significant with the expected sign. Thus, the exports are positively associated with the share a country's workforce in the manufacturing sector, while the imports are negatively associated with this share. It is noteworthy that the coefficient of the variable measuring the imports from the South is significantly higher in absolute value than the coefficients of the other trade variables. This result proves the importance of disaggregating the trade flows into imports and exports, especially the trade flows with the South, an approach not followed by Kang and Lee (2011) when studying the effects of globalization on relative manufacturing employment in economically succesful countries. Interestingly, the coefficients of the two first control variables, i.e. the unemployment rate and the intensity of gross fixed capital formation, become significant with the expected sign when the trade variables are included into the regression. Model 6 shows that the main results from model 5 are still valid in presence of the FDI flows. With respect the FDI-related variables, the coefficients exhibit the expected sign but are unsignificant. Although this last finding might tempt one to conclude that the FDI flows are not an important determinant of structural change, especially of relative manufacturing employment, we do want to caution the reader against jumping too quickly to this conclusion as the FDI flows may have an important role on trade performance ${ }^{52}$

\footnotetext{
${ }^{51}$ Most previous empirical research on deindustrialization focuses on the period starting in 1970.

52 In addition, data on FDI flows in manufacturing could not be used in this study. In a study covering a shorter time period, Kang and Lee (2011) thus find a significant effect of the FDI flows in manufacturing on relative manufacturing employment.
} 
Table 3: FE-PCSE estimates of relative manufacturing employment for 18 OECD countries, 1977-2007

\begin{tabular}{|c|c|c|c|c|c|c|c|}
\hline & Model 1 & Model 2 & Model 3 & Model 4 & Model 5 & Model 6 & Model 7 \\
\hline (Relative manufacturing employment)เ & & & & & & & $\begin{array}{c}0,790 * * * \\
(0,03)\end{array}$ \\
\hline GDP/Capita & $\begin{array}{c}4,693 * * * \\
(0.74)\end{array}$ & $\begin{array}{c}4,574^{* * *} \\
(0,70)\end{array}$ & $\begin{array}{c}4,722^{* * *} \\
(0,74)\end{array}$ & $\begin{array}{c}4,812 * * * \\
(0,79)\end{array}$ & $\begin{array}{c}5,019 * * * \\
(0,71)\end{array}$ & $\begin{array}{c}5,121^{* * *} \\
(0,52)\end{array}$ & $\begin{array}{c}0,736^{* *} \\
(0,35)\end{array}$ \\
\hline$(\text { GDP/Capita })^{2}$ & $\begin{array}{c}-0.225^{* * *} \\
(0.04)\end{array}$ & $\begin{array}{c}-0,219 * * * \\
(0,04)\end{array}$ & $\begin{array}{c}-0,229 * * * \\
(0,04)\end{array}$ & $\begin{array}{c}-0,233^{* * *} \\
(0,04)\end{array}$ & $\begin{array}{c}-0,249 * * * \\
(0,04)\end{array}$ & $\begin{array}{c}-0,248^{* * *} \\
(0,03)\end{array}$ & $\begin{array}{c}-0,038^{* *} \\
(0,02)\end{array}$ \\
\hline $\begin{array}{l}\text { Unbalanced Productivity Growth (UPG) } \\
\text { (IC/GO) in manufacturing }\end{array}$ & $\begin{array}{c}-0.152^{* * *} \\
(0.02)\end{array}$ & $\begin{array}{c}-0,145^{* * *} \\
(0,02) \\
-0,038 \\
(0,12)\end{array}$ & $\begin{array}{c}-0,136^{* * *} \\
(0,02)\end{array}$ & $\begin{array}{c}-0,096^{* * *} \\
(0,02)\end{array}$ & $\begin{array}{c}-0,187^{* * *} \\
(0,02)\end{array}$ & $\begin{array}{c}-0,129^{* * *} \\
(0,02)\end{array}$ & $\begin{array}{c}-0,038^{* * *} \\
(0,01)\end{array}$ \\
\hline Exports to the North (\% GDP) & & & $\begin{array}{l}0,097 \\
(0,07)\end{array}$ & $\begin{array}{l}0,052 \\
(0,08)\end{array}$ & & & \\
\hline Imports from the North (\% GDP) & & & $\begin{array}{r}-0,165 \\
(0,11)\end{array}$ & $\begin{array}{l}-0,071 \\
(0,12)\end{array}$ & & & \\
\hline Exports to the South (\% GDP) & & & $\begin{array}{l}0,224 \\
(0,19)\end{array}$ & $\begin{array}{l}0,113 \\
(0,19)\end{array}$ & & & \\
\hline Imports from the South (\% GDP) & & & $\begin{array}{l}-0,102 \\
(0,33)\end{array}$ & $\begin{array}{l}-0,099 \\
(0,33)\end{array}$ & & & \\
\hline Exports to the North (\% GO in man.) & & & & & $\begin{array}{c}0,204 * * * \\
(0,04)\end{array}$ & $\begin{array}{c}0,354^{* * *} \\
(0,05)\end{array}$ & $\begin{array}{c}0,061^{* *} \\
(0,02)\end{array}$ \\
\hline Imports from the North (\% GO in man.) & & & & & $\begin{array}{c}-0,272^{* * *} \\
(0,06)\end{array}$ & $\begin{array}{c}-0,487^{* * *} \\
(0,08)\end{array}$ & $\begin{array}{c}-0,095^{* * *} \\
(0,03)\end{array}$ \\
\hline Exports to the South (\% GO in man.) & & & & & $\begin{array}{c}0,288^{* * *} \\
(0,12)\end{array}$ & $\begin{array}{c}0,407^{* * *} \\
(0,12)\end{array}$ & $\begin{array}{c}0,205^{* * *} \\
(0,07)\end{array}$ \\
\hline Imports from the South (\% GO in man.) & & & & & $\begin{array}{c}-0,874^{* * *} \\
(0,15)\end{array}$ & $\begin{array}{c}-1,234^{* * *} \\
(0,15)\end{array}$ & $\begin{array}{c}-0,329 * * * \\
(0,11)\end{array}$ \\
\hline Inward FDI & & & & $\begin{array}{c}0,0002 \\
(0,00)\end{array}$ & & $\begin{array}{c}0,0004 \\
(0,00)\end{array}$ & \\
\hline Outward FDI & & & & $\begin{array}{c}-0,0001 \\
(0,00)\end{array}$ & & $\begin{array}{c}-0,0001 \\
(0,00)\end{array}$ & \\
\hline Unemployment & $\begin{array}{l}-0.012 \\
(0.01)\end{array}$ & $\begin{array}{c}-0,012 \\
(0,01)\end{array}$ & $\begin{array}{l}-0,014^{*} \\
(0,008)\end{array}$ & $\begin{array}{l}-0,015^{*} \\
(0,007)\end{array}$ & $\begin{array}{c}-0,017^{* *} \\
(0,007)\end{array}$ & $\begin{array}{c}-0,017^{* *} \\
(0,007)\end{array}$ & \\
\hline Gross fixed Capital Formation & $\begin{array}{r}-0,021 \\
(0.02)\end{array}$ & $\begin{array}{r}-0,022 \\
(0,02)\end{array}$ & $\begin{array}{l}0,002 \\
(0,02)\end{array}$ & $\begin{array}{l}0,008 \\
(0,02)\end{array}$ & $\begin{array}{c}0,065^{* * *} \\
(0,02)\end{array}$ & $\begin{array}{c}0,106^{* * *} \\
(0,02)\end{array}$ & \\
\hline Labor maket participation of women & $\begin{array}{c}-0,129 * * * \\
(0,04)\end{array}$ & $\begin{array}{c}-0,133^{* * *} \\
(0,04)\end{array}$ & $\begin{array}{c}-0,197^{* * *} \\
(0,04)\end{array}$ & $\begin{array}{c}-0,176^{* * *} \\
(0,04)\end{array}$ & $\begin{array}{c}-0,154^{* * *} \\
(0,04)\end{array}$ & $\begin{array}{c}-0,191^{* * *} \\
(0,04)\end{array}$ & $\begin{array}{c}-0,043^{* *} \\
(0,02)\end{array}$ \\
\hline Observations & 540 & 540 & 540 & 480 & 540 & 480 & 522 \\
\hline
\end{tabular}

Note. - Numbers in parentheses are SEs. Controls for fixed effects and period effects are included in all models. ${ }^{*} \mathrm{P}<.1 ;{ }^{* *} \mathrm{P}<.05 ;{ }^{* * *} \mathrm{P}<0.0$ 
Using the regression coefficients from model 5 along with the actual data, we reproduce the exercise proposed by Kollmeyer (2009) in order to quantify the relative importance of trade in manufactures as a key factor contributing to deindustrialization in advanced countries. The results are shown in table 4 below. Based on our calculations, global trade affected negatively relative manufacturing employment in virtually all countries, with the exceptions of Ireland and Austria, over the period 1977-2007. While the direct contribution of trade in manufactures to deindustrialization seems to be relatively small for countries like Sweden (0.3\%), Finland (5.8\%) or Germany (9\%), it is contrastingly large for countries like the US (30.2\%), the UK (34.4\%), Australia (39.9\%) or Greece (41.6\%). It is noteworthy that the evolution of North-South trade has contributed negatively to relative manufacturing employment in all selected advanced countries. The view is more nuanced for North-North trade, as it has contributed negatively to relative manufacturing employment in countries like Austria, Germany and Netherlands, while it has speeded up deindustrialization in countries like France, Portugal and Spain. Generally speaking, our estimates exceed those of Kollmeyer (2009:1666) for the Group of Seven (G-7) countries. While they do not contradict the widespread belief that 'internal' factors are more important in accounting for deindustrialization in advanced countries taken as whole, they indicate that trade may have played an important role in relative manufacturing decline in a number of countries, especially as trade has also affected indirectly relative manufacturing employment by enhancing the growth of income (GDP per capita) and relative labor productivity in the manufacturing sector. The impact of trade may also have to be revised upwards taking into account the FDI flows in manufacturing and the offshoring of certain services that were previously performed domestically in the manufacturing firms.

Table 4: Direct Contribution of Trade to Deindustrialization for 18 OECD Countries, 1977-2007

\begin{tabular}{|c|c|c|c|c|}
\hline & \multirow[b]{2}{*}{$\begin{array}{l}\text { Percentage-Point Drop in } \\
\text { relative manufacturing } \\
\text { employment, } 1977-2007\end{array}$} & \multicolumn{3}{|c|}{ Attributable $\%$ of Change } \\
\hline & & $\begin{array}{c}\text { North-North } \\
\text { Trade }\end{array}$ & $\begin{array}{c}\text { North-South } \\
\text { Trade }\end{array}$ & Trade \\
\hline Australia & $-11,0$ & 8,0 & 31,9 & 39,9 \\
\hline Austria & $-9,6$ & $-8,8$ & 8,7 & $-0,1$ \\
\hline Canada & $-7,3$ & $-3,9$ & 25,8 & 21,9 \\
\hline Denmark & $-7,1$ & 0,3 & 14,0 & 14,3 \\
\hline Finland & $-5,2$ & $-3,9$ & 9,7 & 5,8 \\
\hline France & $-9,4$ & 6,4 & 10,6 & 17,0 \\
\hline Germany & $-10,8$ & $-5,2$ & 14,3 & 9,0 \\
\hline Greece & $-8,1$ & 14,8 & 26,8 & 41,6 \\
\hline Ireland & $-7,3$ & $-40,6$ & 15,2 & $-25,3$ \\
\hline Italy & $-9,4$ & 4,0 & 10,4 & 14,4 \\
\hline Japan & $-4,8$ & $-0,1$ & 13,4 & 13,2 \\
\hline Netherlands & $-9,5$ & $-15,0$ & 29,9 & 14,9 \\
\hline Norway & $-8,1$ & $-1,3$ & 14,8 & 13,5 \\
\hline Portugal & $-4,5$ & 20,0 & 7,5 & 27,5 \\
\hline Spain & $-7,9$ & 13,2 & 19,4 & 32,6 \\
\hline Sweden & $-7,2$ & $-4,0$ & 4,4 & 0,3 \\
\hline United Kingdom & $-17,4$ & 8,2 & 26,2 & 34,4 \\
\hline United States & $-10,1$ & 4,5 & 25,6 & 30,2 \\
\hline
\end{tabular}


Model 7 in table 3 shows the results from our dynamic LDV model. When one lag of the dependent variable is included as an explanatory variable into the regression, the labor market participation rate of women is the only control variable that remains significant. The two other control variables, namely the unemployment rate and the intensity of gross fixed capital formation, are therefore removed from the regression. As it might be expected, the sectoral structure of employment evolves relatively slowly over time. The autoregressive coefficient is indeed equal to 0.79 , which implies a relatively low speed of adjustment. All the variables of interest remain significant, but the magnitude of the coefficients and standard errors is substantially lowered. If such a result could raise concern about the validity of the dynamic specification in the presence of unaddressed serial autocorrelation (see Achen, 2001), it rather seems to be suggesting here that it will take time for the system to fully adjust to variations in the explanatory variables. Interestingly, the inclusion of the time dummies seems to be less important in the dynamic specification. With the exception of a few years, the time dummies are not significant at the conventional levels of significance. This result does not give strong support to the assumption formulated by Kollmeyer (2009) that the high significance of the time dummies in the static regressions could be due to hardly measurable outsourcing of activities once performed by manufacturing firms themselves, but rather tends to attribute this statistical finding to the absence or lack of dynamics in the models.

\section{The macroeconomic consequences of deindustrialization}

The process of deindustrialization has commonly been associated with relative economic decline in advanced economies. The literature is full of examples of regions or cities where deindustrialization, characterized by massive shutdown and job losses in the manufacturing sector, has coincided with a period of socioeconomic dislocation. In line with these deindustrialization stories, a large number of scholars have emphasized the 'socioeconomic costs' supposedly implied by the phenomenon. These costs can take a myriad of forms. Deindustrialization has thus been blamed, among others, for rising unemployment and poverty in a number of older industrial regions, which in turn has been translated into higher economic inequality (see e.g. Doussard et al., 2009), lower individual economic aspirations, motivations and expectations (see e.g. Beck, 2000; Meyer, 2009; Sissons, 2009; compare Ackers, 2014), lower ability to finance public education (see e.g. Spayd and Dye, 1991; Bettis, 1994), poorer health conditions (see e.g. Renner and Navarro, 1989; Wallace D. and Wallace R., 1999; Ostry et al., 2002; EIR, 2006; Holland et al., 2011), higher violence (see e.g. Ousey, 2000; Matthews et al., 2001), and higher rates of both suicide (see e.g. Kubrin et al., 2006) and mortality (see e.g. EIR, 2006; Hanlon et al., 2010). While deindustrialization can truly have some devastating socioeconomic effects on local communities in the regions that are especially affected by the erosion of manufacturing employment, it is incredibly hard to assess the aggregated impact of deindustrialization at national level, as economic restructuring involves a number of redistributive effects. By way of illustration, trade-led deindustrialization may be totally or partially offset by the fast growth of tradeable services resulting from specialization patterns driven by comparative advantage. In the same vein, technology-led deindustrialization takes place as part of a process of 'creative destruction' - as Schumpeter (1942) called it - rewarding the successful innovators and destroying old sources of competitive advantage, those exploited by the operators of the incumbent technologies. Thus, despite a severe economic downturn in older industrial cities of the 
New England, Mid-Atlantic, and Midwest regions of the USA, which was supposedly due to the collapse of their manufacturing sectors, Reardon (2005) notices that the period between 1970 and 1990 was, with the exception of a few years, a time of significant and sustained growth in the US economy as a whole. Focusing on the British economy, other scholars have contrastingly blamed deindustrialization for inferior growth and productivity improvement during the postwar period (see e.g. Kitson and Michie, 1996, 1997 and 2014). In line with this view, the alarming hypothesis of deindustrialization as the main factor responsible for current slow economic growth in advanced countries, which some economists believe to be the onset of a 'secular stagnation', has also gained in popularity in recent years as the share of manufacturing in total workforce is reaching lower and lower levels.

From a theoretical point of view, the impact of deindustrialization on growth critically depdends on whether or not growth is 'sector-indifferent'. Distinguishing between the concepts of 'activity' and 'sector', Palma (2014) has recently proposed to classify growth theories into three camps. The first camp includes the theories that view growth as both 'sector-indifferent' and 'activity-indifferent'. Examples are Solow-type models and the branch of endogenous theories that associates growth with increasing returns which are activity-indifferent, i.e. not based on the use of R\&D or the production of human capital. The second camp argues that growth is 'sector-indifferent' but 'activity-specific'. In these growth models, like Romer's work and neo-Schumpeterian models, increasing returns, though generated by R\&D activities, are explicitly not associated with manufacturing activities as such. The third camp gathers the theories regarding growth as both 'sector-specific' and 'activity-specific'. In these growth theories, including mainly Post-Keynesian, Schumpeterian and structuralist theories, the pattern and dynamic of growth are crucially dependent on the activities being developed, with the latter being specific to the nature of the sector involved, thus opening ways for Kaldorian-style effects concerning investment embedding or embodying technological change. As noted by Palma (2014:21), "the crucial difference between this camp and the previous two ones is that issues such as technological change, externalities, synergies, balance-of-payments sustainability, and the capacity of developing countries to 'catch up', are in fact directly linked to the size, strength and depth of the manufacturing sector".

Generally speaking, any multi-sector model's predictions of the long-run growth consequences of deindustrialization depends on its ability to generate structural change, including deindustrialization, along a balanced growth path (BGP). If this is the case, structural change is arguably viewed as growthneutral. If this not the case, deindustrialization is then usually viewed as economically harmful because the manufacturing sector is usually believed to exhibit higher potential for technological (productivity) advance. Thus, while the theoretical multi-sector models proposed by Baumol (1967) and Acemoglu and Guerrieri (2008) predict unbalanced growth, with the long-run growth rate of the economy being determined by the asymptotically dominant sector, the services sector and the labor-intensive sector respectively, Ngai and Pissarides (2007) construct a multi-sector model of growth in which structural change takes place along a balanced growth path. A number of emprirical studies have been devoted to quantifying the effect of deindustrialization on (productivity) growth. Such an exercise can be done in a variety of ways, ranging from the use of growth accounting techniques, like the canonical shiftshare method, to econometric analysis. As recently pointed out by Tregenna (2015:34), this empirical 
literature ${ }^{53}$ is however inconclusive: "The empirical evidence is mixed. A positive relationship between manufacturing and growth is found in several studies, but there is large variation in this relationship, including for different periods of time." While acknowledging the unclearness of the empirical results, Tregenna (2015) argues that the likely growth effects of deindustrialization should depdend inter alia on the level of income per capita and the degree of industrialization at which deindustrialization starts; on the nature of deindustrialization, including both its causes and its dynamics; on the nature of the manufacturing activities that are in relative decline and of the activities, both manufacturing and nonmanufacturing, that are relatively growing ${ }^{54}$.

Independently from the desirability of deindustrialization, whose assessment is multidimensional, the question of whether or not deindustrialization is avoidable has also been tackled in the literature as it has very important policy implications. The answer to this research question critically depends on the extent to which researchers are willing to acknowledge deindustrialization as an endogenous process progressively taking place over time with economic development and arising as an efficient equilibrium outcome, what economists have sometimes referred to as 'positive deindustrialization'. While it seems to be increasingly accepted among the scientific community that the decline in relative manufacturing employment is a natural phenomenon in advanced countries, it is also widely believed that the pace at which deindustrialization takes place in a country is subject to policy interventions, as well as to the country's position in international trade. Deindustrialization indeed occurs in an interdependent world, thus requiring a global analysis that should go beyond the separate study of national experiences, and can truly be accelerated by a policy change or more generally by the lack of support to manufacturing. If manufacturing is considered as having special properties as an engine of growth, then policy-induced or trade-driven deindustrialization that would be characterized by a large loss of industrial substance, measured in terms of technical know-how and innovative capacities, may be economically damaging, especially as there is evidence showing that deindustrialization is associated with a deterioration of the trade balance in a number of countries, with potential implications for the ability to finance imports and maintain living tandards (see e.g. Kitson and Michie, 1997; Legarda and Blazquez, 2013; McKinnon, 2013). This is probably why many scholars have forcefully called for reindustrialization in the Western countries, arguing that the decline in relative manufacturing employment could be slowed down or even temporarily reversed with an active industrial policy that would, among others, help in exploiting the opportunities offererd by foreign trade, for instance through a growing specialization in high-value added goods or high-value added segments of increasingly global value chains, and build strong linkages between the manufacturing sector and other activities like services to increase the scope for positive externalities and interaction effects. As noted by Tregenna (2015:49), industrial policy alone is however not enough to strenghthen a country's manufacturing base. To be fully effective, industrial policy needs to be complemented by a supportive macroeconomic policy, especially regarding the interest and exchange rates, and appropriate trade policy, technology policy, labour market policy and skills and education policies. Regarding this point, Crafts (1996) early advocated in favor of a supplyside policy that would not place too much focus on the decline in relative manufacturing employment,

\footnotetext{
${ }^{53}$ See e.g. Pieper (2000), Dasgupta and Singh (2006), Szirmai and Verspagen (2011), Szirmai (2012), and Naudé et al. (2013). ${ }^{54}$ By way of illustration, Stijepic and Warner (2008) show, by the use of a multisector-growth-model where the sectors differ by their TFP-growth, that offshoring, through generating structural transformation, influences the long run growth rate of the economy along different channels and that the growth effects are dependent on the evolution of terms of trade and on whether low-productivity-growth-activities or high-productivity-growth activities are offshored.
} 
viewed as a 'distraction' because it is "an inherent part of a process of raising the growth rate by improving the appropriability of returns to innovation and liberalizing the economy" (p.181), but would rather address the substantial issues over the human capital formation and technical capabilities of manufacturing ${ }^{55}$, and over investment attractiveness, defined as a country's ability to attract foreign direct investment. In Crafts' mind, investment attractiveness is crucial to ensure that knowledge available from abroad will be used effectively and speedily. Labour market policy, along with education policy, also crucially matter as they will contribute to determining the speed of structural change and the ease with which labor will move from one sector to another. Thompson et al. (2012) thus argue that the potential gains from international trade, which induces some structural change, are directly linked to the degree of flexibility of the economy, especially of the labour market, thus joining many trade theorists' idea that the effects of trade on unemployment highly depend on labor market institutions, i.e. on differences in labor market frictions across industries and countries (see e.g. Stijepic and Wagner, 2008; Helpman and Itskhoki, 2010; Fugazza et al., 2014) ${ }^{56}$. In line with this view, the decades-long contraction of the manufacturing sector has often been blamed for the persistently high unemployment rates observed in advanced countries since the mid-1970s (see e.g. Bluestone, 1983; Bonoli, 200657; Sissons, 2009; Webster, 2010; Kollmeyer, 2013).

\section{Conclusion}

Deindustrialization is one of the best-established stylized facts associated with the process of economic development in advanced economies. Yet the causes and consequences of the phenomenon are still not fully understood, which contributes to feeding into scientific and political discussions, especially as there is a longstanding tradition in economics which argues that manufacturing industry has a critical role in growth (Weiss and Jalilian, 2016). This paper, which joins the debate on the causes of the decline in relative manufacturing employment, does not contradict the widespread belief that internal factors, such as economic affluence and unbalanced productivity growth, are quantitatively more important in explaining deindustrialization in the advanced countries taken as a whole. Nevertheless, it shows that globalization, through both direct and indirect effects, may have accounted for higher proportions than long believed in a number of countries. This result notably lies on the definition of new trade variables designed to capture the effects of globalization on relative manufacturing employment. Regarding this last point, the recent development of statistics on trade flows expressed in value added terms, as well as more precise data on FDI flows and offshoring, should help to enhance and refine the results in the future.

\footnotetext{
${ }^{55}$ Regarding this point, Bernard et al. (2016) have recently stressed the importance of a supply-side policy that focuses not only on manufacturing but also on services as there esist service sector firms, notably composed of firms that once operated in the manufacturing sector, the so-called 'switchers out of manufacturing', that still perform many of the high value-added activities of a typical traditional manufacturing firm.

${ }^{56}$ See e.g. Belenkiy and Riker (2015) for a survey of the recent literature, both theoretical and empirical, linking international trade to unemployment rates.

57 Bonoli (2006:3) thus argues that "current long term unemployment [in developed market economies] has essentially two roots: deindustrialization and the institutional rigidities in service-based labour markets".
} 


\section{Bibliography}

Achen C.H. (2001). "Why Lagged Dependent Variables Can Suppress the Explanatory Power of Other Independent Variables." Department of Political Science and Institute for Social Research, University of Michigan.

Available at: $\underline{\text { https://www.princeton.edu/csdp/events/Achen121201/achen.pdf }}$

Acemoglu D., Carvalho V.M., Ozdagar A. and Tahbaz-Salehi A. (2012). "The Network Origins of Aggregate Fluctuations." In: Econometrica, 80(5), pp.1977-2016.

Acemoglu D. and Guerrieri V. (2008). “Capital Deepening and Non-Balanced Economic Growth”. In: Journal of Political Economy, 116(3), pp.467-498.

Ackers G.K. (2014). “Rethinking deindustrialization and male career crisis.” In: British Journal of Guidance \& Counseling, 42(5), pp. $500-510$

Alderson A. (1997). “Globalization and Deindustrialization: Direct Investment and the Decline of Manufacturing Employment in 17 OECD Nations." In: Journal of World Systems Research, 3, pp. 1-34.

Alderson A. (1999). “Explaining Deindustrialization: Globalization, Failure, or Success?” In: American Sociological Review, 64(5), pp.701-21.

Altena B. and Van der Linden M. (2002). “Preface.” In: International Review of Social History, 47, pp. 1-2

Alvarez-Cuadrado F., van Long N. and Poschke M. (2015). “Capital-Labor Substitution, Structural Change, and Growth". IZA Discussion Paper No. 8940.

Available at: http://ftp.iza.org/dp8940.pdf

Amiti M. and Konings J. (2007). "Trade Liberalization, Intermediate Inputs and Productivity." In: American Economic Review, 97(5), pp. 1611-1638.

Amiti M., and Wei S.-J. (2009). "Service Offshoring and Productivity: Evidence from the US." In: The World Economy, 32(2), pp. 203-220.

Anderson T.W. and Hsiao C. (1981). "Estimation of Dynamic Models with Error Components." In: Journal of the American Statistical Association, 76(375), pp. 598-606

Anderson T.W. and Hsiao C. (1982). "Formulation and estimation of dynamic models using panel data." In: Journal of Econometrics, 18(1), pp. 47-82

Arellano M. and Bond S. (1991). "Some Tests of Specification for Panel Data: Monte Carlo Evidence and an Application to Employment Equations." In: Review of Economic Studies, 58(2), pp. 277-297

Arellano M. and Bover O. (1995): “Another Look at the Instrumental-Variable Estimation of Error-Components Models." In: Journal of Econometrics, 68(1), pp. 29-51

Arellano M. (2003). Panel Data Econometrics. Oxford University Press, Oxford

Autor D.H. and Dorn D. (2013). "The Growth of Low-Skill Service Jobs and the Polarization of the US Labor Market." In: The American Economic Review, 103(5), pp.1553-1597.

Autor D.H., Dorn D. and Hanson G.H. (2013). "The China Syndrome: Local Labor Market Effects of Import Competition in the United States." In: American Economic Review, 103(6), pp.2121-2168.

Autor D.H., Katz L.F. and. Kearney M.S. (2006). “The Polarization of the U.S. Labor Market.” In: The American Economic Review, 96(2), pp.189-194. 
Autor D.H., Levy F. and Murnane R.J. (2003). "The Skill Content of Recent Technological Change: An Empirical Exploration." In: The Quarterly Journal of Economics, 118(4), pp.1279-1333.

Barani Z.L. and Siegel C. (2014). “Job Polarization and Structural Change."

Available at: $\underline{\text { http://cep.lse.ac.uk/seminarpapers/17-05-14-ZB.pdf }}$

Barani Z.L. and Siegel C. (2015). “Job Polarization and Structural Change.”

Available at: http://people.exeter.ac.uk/cs441/researchpapers/polarization structural change.pdf

Barton R. (2015). "'Good Riddance to the Stinkin' Place": Deindustrialisation and Memory at Associated Pulp and Paper Mills in Burnie, Tasmania." In: Labour History, Issue 109, pp. 149-167

Baumol W.J. (1967). "Macroeconomics of unbalanced growth: the anatomy of urban crisis". In: American Economic Review, 57(3), pp.415-426.

Baumol W.J., Blackman S.A.B. and Wolff E.N. (1985). “Unbalanced growth revisited: asymptotic stagnancy and new evidence”. In: American Economic Review, 75(4), pp.806-817

Baumol W.J., Blackman S.A.B. and Wolff E.N. (1989). Productivity and American Leadership: The Long View. Cambridge, Mass.: MIT Press

Beck U. (2000). The brave new world of work. Cambridge: Polity Press

Beck N. and Katz J.N. (1995). "What to do (and not to do) with time-series cross-section data." In: The American Political Science Review, 89(3), pp. 634-647

Beck N. and Katz J.N. (1996). “Nuisance vs. substance: specifying and estimating time-series cross-section models.” In: Political analysis, 6(1), pp. 1-36

Beck N. and Katz J.N. (2011). “Modeling Dynamics in Time-Series-Cross-Section Political Economy Data." In: Annual Review of Political Science, 14, pp. 331-352

Belenkiy M. and Riker D. (2015). "Theory and Evidence Linking International Trade to Unemployment rates." U.S. International Trade Commission, Office of Economics Working Paper No. 2015-01B.

Available at: https://www.usitc.gov/publications/332/ec201501b.pdf

Bell D. (1976). The Coming of Post-industrial Society. Harmondsworth, Penguin Books.

Berlingieri G. (2014). “Outsourcing and the Rise in services.” LSE Centre for Economic Performance Discussion Paper 1199.

Available at: http://cep.lse.ac.uk/pubs/download/dp1199.pdf

Bernard A.B., Smeets V. and Warzynski F. (2016). "Rethinking Deindustrialization." Centre for Economic Performance, London School of Economics, CEP Discussion Paper No 1423, April 2016

Bettis P.J. (1994). “Deindustrialization and urban scholls: Some theoretical considerations.” In: The Urban Reviewl, 26(2), pp. 75-94

Bhagwati J., Panagariya A. and Srinivasan T.N. (2004). "The Muddles over Outsourcing." In: Journal of Economic Perspectives, 18(4), pp. 93-114

Blackburn III E.F. and Frank M.W. (2007). “Estimation of nonstationary heterogeneous panels.” In: The Stata Journal, 7(2), pp. 197-208

Blinder A. (2007). “Offshoring: Big Deal or Business as Usual?” CEPS Working Paper No. 149.

Bluestone B. (1983). "Deindustrialization and unemployment in America." In: The Review of Black Political Economy, 12(3), pp. 27-42 
Bluestone B. and Harrison B. (1982). The Deindustrialization of America: Plant Closing, Community Abandonment, and the Dismantling of Basic Industry. New York: Basic Books.

Blundell R. and Bond S. (1998). "Initial Conditions and Moment Restrictions in Dynamic Panel Data Models." In: Journal of Econometrics, 87(1), pp. 115-143.

Blundell R. and Bond S. (2000). "GMM Estimation with Persistent Panel Data: An Application to Production Functions." In: Econometric Reviews, 19(3), pp. 321-340.

Bonoli G. (2006). "Adapting Employment Policies to Post-Industrial Labour Market Risks." Working Paper de l'IDHEAP No. $6 / 2006$.

Available at: $\underline{\text { http://citeseerx.ist.psu.edu/viewdoc/download?doi=10.1.1.603.543\&rep=rep1\&type=pdf }}$

Brady D. and Denniston R. (2006). “Economic globalization, Industrialization and Deindustrialization”. In: Social Forces, 85(1), pp.297-329.

Bruno G.S.F. (2005a). "Estimation and inference in dynamic unbalanced panel-data models with a small number of individuals." In: The Stata Journal, 5(4), pp. 473-500

Bruno G.S.F. (2005b). "Approximating the bias of the LSDV estimator for dynamic unbalanced panel data models." In: Economic Letters, 87(3), pp. 361-366

Buera F.J. and Kaboski J.P. (2012a). "The Rise of the Service Economy". In: American Economic Review, 102(6), pp.2540-2569.

Buera F.J. and Kaboski J.P. (2012b). "Scale and Origins of Structural Change". In: Journal of Economic Theory, 147(2), pp.684712.

Bun M.J.G. and Kiviet J.F. (2003). "On the diminishing returns of higher order terms in asymptotic expansions of bias." In: Economic Letters, 79(2), pp. 145-152

Byrne D. (1980). "The Deindustrialization of Northern Ireland". In: Antipode, 12(1), pp.87-96

Caselli F. and Coleman II W.J. (2001). "The U.S. structural transformation and regional convergence: a reinterpretation". In: Journal of Political Economy, 109 (3), pp. 584-616.

Chen t.-J. and Chen Y-P. (1995). "Foreign Direct Investment and Deindustrialisation: The Case of Taiwan." In: Journal of Industry Studies, 2(1), pp. 57-68

Clark C. (1940). The Conditions of Economic Progress. Macmillan, New York.

Clark C. (1957). The Conditions of Economic Progress. MacMillan and Company (London), $3^{\text {rd }}$ edition

Clark G. (2014). "The Industrial Revolution." In: Aghion P. and Durlauf S. (eds.), Handbook of Economic Growth, Volume 2, North-Holland, pp. 217-262.

Cowie J. and Heathcott (Eds.). Beyond the Ruins: The meanings of Deindustrialization. Ithaca, N.Y.: Cornell University Press, $2003,372 \mathrm{p}$.

Crafts N. (1996). “Deindustrialization and Economic Growth.” In: The Economic Journal, 106(434), pp. 172-183.

Craighead W.D. and Hineline D.R. (2015). "Current Account Reversals and Structural Change in Developing and Industrialized Countries." In: The Journal of International Trade \& Economic Development: An International and Comparative Review, 24(1), pp. 147-171

Dandaneau S.P. (2012). "Critical Theory, Legitimation Crisis, and the Deindustrialization of Flint, Michigan”. In: Kivisto P. (ed.), Illuminating Social Life: Classical and Contemporary Theory Revisited, chapter 7, SAGE Publications, 440 p.

Dasgupta S. and Singh A. (2006). "Manufacturing, Services and Premature Deindustrialization in Developing Countries: A Kaldorian Analysis." UNU-WIDER, United Nations University Research Paper, No. 2006/49.

Demmou (2010). “La désindustrialisation en France.” In : Les Cahiers de la DG Trésor, No. 2010-01, Juin 2010, pp.1-50. 
Dodzin S. and Vamvakidis A. (2004). "Trade and industrialization in developing economies." In: Journal of Development Economics, 75(1), pp.319-328

Doussard M., Peck J. and Theodore N. (2009). "After Deindustrialization: Uneven Growth and Economic Inequality in "Postindustrial” Chicago." In: Economic Geography, 85(2), pp. 183-207.

EIR (2006). "The case of Baltimore: Deindustrialization Creates 'Death Zones'."

Available at: $\underline{\text { http://www.larouchepub.com/eiw/public/2006/2006 1-9/2006-1/pdf/04-27 } 601 \text { featbalt.pdf }}$

Engle R.F. and Granger C.W.J. (1987). "Co-Integration and Error Correction: Representation, Estimation, and Testing." In: Econometrica, 55(2), pp. 251-276

Feng A. and Graetz G. (2015). "Rise of the Machines: The Effects of Labor-Saving Innovations on Jobs and Wages." CEP Discussion Paper, CEPDP 1330. Centre for Economic Performance, London school of Economics and Political Science.

Available at: $\underline{\text { http://eprints.Ise.ac.uk/61028/ }}$

Fisher A.G.B. (1939). “Primary, Secondary and Tertiary Production”. In: Economic Record, 15(28), pp. 24-38.

Foellmi R. and Zweimüller J. (2008). "Structural change, Engel's consumption cycles and Kaldor's facts of economic growth". In: Journal of Monetary Economics, 55(7), pp.1317-1328.

Fourastié J. (1949). Le grand espoir du XXème siècle. Paris, PUF.

Freeman R.B. and Schettkat R. (2005). "Marketization of Household Production and the EU-US Gap in Work." In: Economic Policy, 20(41), pp.7-50

Fuchs V. (1968). The Service Economy. Columbia University Press, New York and London.

Fugazza M., Carrère C., Olarreaga M. and Robert-Nicoud F. (2014). "Trade in Unemployment." Policy Issues in International Trade and Commodities, Research Study Series No. 64

Available at: http://unctad.org/en/PublicationsLibrary/itcdtab64 en.pdf

Gaston N. (1998). "The Impact of International Trade and Protection on Australian Manufacturing employment." In: Australian Economic Papers, 37(2), pp. 119-136

Gengenbach C., Urbain J.-P. and Westerlund J. (2009). Error Correction Testing in Panels with Global Stochastic Trends (December 2009). Maastricht University: METEOR.

Gille B. (1978). Histoire des techniques. Gallimard La Pléiade

Goch S. (2002). "Betterment without Airs: Social, Cultural, and Political Consequences of De-industrialization in the Ruhr." In: International Review of Social History, 47, pp. 87-111.

Goldberg P.K., Khandelwal A.K., Pavcnik N. and Topalova P. (2010). "Imported Intermediate Inputs and Domestic Product Growth: Evidence from India." In: The Quarterly Journal of Economics, 125(4), pp. 1727-1767

Goos M., Manning A. and Salomons A. (2014). "Explaining Job Polarization: Routine-Biased Technological Change and Offshoring." In: The American Economic Review, 104(8), pp.2509-2526.

Grossman G.M. and Helpman E. (2005). "Outsourcing in a Global Economy." In: Review of Economic Studies, 72(252), pp. 135159.

Hanlon P., Taulbut M. and Walsh D. (2010). "The aftershock of deindustrialization - trends in mortality in Scotland and other parts of post-industrial Europe." In: The European Journal of Public Health, 20(1), pp.58-64

Hartwig J. (2015). "Structural change, aggregate demand and employment dynamics in the OECD, 1970-2010." In: Structural Change and Economic Dynamics, 34, pp.36-45. 
Helpman E. and Itskhoki O. (2010). "Labor Market Rigidities, Trade and Unemployment." In: Rdeview of Economic Studies, 77(3), pp. 1100-1137

Herrendorf B., Rogerson R. and Valentinyi A. (2014). "Growth and Structural Transformation". In: Aghion P. and Durlauf S.N. (eds.), Handbook of Economic Growth, Volume 2, chapter 6, pp.855-941.

High S. (2013). "'The Wounds of Class": A Historiographical Reflection on the Study of Deindustrialization, 1973-2013." In: History Compass, 11(11), pp. 994-1007

Holland P., Burstrom B., Whitehead M., Diderichsen F., Dahl E., Barr B., Nylen L., Chen WH, Thielen K., van der Wel K.A., Clayton S. and Uppal S. (2011). "How do macro-level contexts and policies affect the employment chances of chronically ill and disabled people? Part I: The impact of recession and deindustrialization." In: International Journal of Health Services, 41(3), pp. 395-413

Im K.S., Pesaran M.H. and Shin Y. (2003). "Testing for unit roots in heterogeneous panels." In: Journal of Econometrics, 115(1), pp. 53-74

Imbs J. (2013). "The Premature Deindustrialization of South Africa". In: Stiglitz J.E., Esteban J., Lin J.Y. and Patel E. (eds.), The Industrial Policy Revolution II: Africa in the Twenty-first Century, Palgrave Macmillan, pp.529-540.

Imbs J., Montenegro C. and Wacziarg R. (2012). “Economic Integration and Structural Change”. Working Paper.

Available at http://www.tse-fr.eu/sites/default/files/medias/stories/sem 12 13/eco politique/imbs.pdf

Judson R.A. and Owen A.L. (1999). "Estimating dynamic panel data models: a guide for macroeconomists". In: Economic Letters, 65(1), pp. 9-15.

Kang S.J. and Lee H. (2011). “Foreign Direct Investment and De-industrialisation.” In: The World Economy, 34(2), pp. 313-329.

Kao C. (1999). "Spurious Regression and Residuals based tests for cointegration in panel data." In: Journal of Econometrics, 90(1), pp. 1-44

Kasahara H. and Rodrigue J. (2008). “Does the Use of Imported Intermediates Increase Productivity?” In: Journal of Development Economics, 87(1), pp. 106-118.

Katouzian M.A. (1970). "The development of the service sector: a new approach." In: Oxford Economic Papers, 22(3), pp.362382.

Kitson M. and Michie J. (1996). "Britain's Industrial Performance Since 1960: Underinvestment and Relative Decline." In: The Economic Journal, 106(434), pp. 196-212

Kitson M. and Michie J. (1997). “Does Manufacturing Matter? International Journal of the Economics of Business, 4(1), pp. 7195.

Kitson M. and Michie J. (2014). "The de-industrial revolution: the rise rise and fall of UK manufacturing, 1870-2010". In: Floud R., Humphries J. and Johnson P. (eds.), The Cambridge Economic History of Modern Britain, Volume 2, Growth and Decline, 1870 to the Present, Cambridge University Press, pp. 302.329

Kiviet J.F. (1995). “On bias, inconsistency and efficiency of various estimators in dynamic panel data models." In: Journal of Econometrics, 68(1), pp. 53-78

Kiviet J.F. (1999). "Expectation of Expansions for Estimators in a Dynamic Panel Data Model: Some Results for Weakly Exogenous regressors." In: Hsiao C., Lahiri K., Lee L.-F., Pesaran M.H. (Eds.), Analysis of Panel Data and Limited Dependent Variables. Cambridge University Press, Cambridge.

Koistinen D. (2006). "Public Policies for Countering Deindustrialization in Postwar Massachusetts." In: Journal of Policy History, 18(3), pp. 326-361

Kollmeyer C. (2009). "Explaining Deindustrialization: How Affluence, Productivity Growth, and Globalization Diminish Manufacturing Employment." In: American Journal of Sociology, 114(6), pp. 1644-1674 
Kollmeyer C. (2013). "Is Deindustrilaization Causing High Unemployment in Affluent Countries? Evidence from 16 OECD Countries, 1970-2003." In: Social Forces, 91(3), pp. 785-812.

Kongsamut P., Rebelo S. and Danyang X. (2001). "Beyond balanced growth". In: Review of Economic Studies, 68(4), pp.869882

Kravis I.B., Heston A.W. and Summers R. (1983). "The Share of Services in Economic growth". In: Adams F.G. and Hickman B.G. (eds.), Global Econometrics: Essays in Honor of Lawrence R. Klein, Cambridge, MA, and London: MIT Press, pp.188-218

Krugman P. (1996). “Domestic Distorsions and the Deindustrialization Hypothesis.” NBER Working Paper No. 5473

Krugman P. and Lawrence R.Z. (1993). "Trade, Jobs, and Wages." Working paper no. 4478. National Bureau of Economic Research, Cambridge, Mass

Kubrin C.E., Wadsworth T.P. and DiPietro S. (2006). "Deindustrialization, disadvantage and suicide among young black males." In: Social Forces, 84(3), pp. 1559-1579

Kucera D. and Milberg W. (2003). "Deindustrialization and Changes in Manufacturing Trade: Factor Content Calculations for 1978-1995." In: Review of World Economics/Weltwirtschaftliches Archiv, 139(4), pp. 601-24.

Kudina A. and Pitelis C. (2014). "De-industrialisation, comparative economic performance and FDI inflows in emerging economies." In: International Business Review, 23(5), pp. 887-896

Kuznets S. (1973). “Modern Economic Growth: Findings and Reflections". In: American Economic Review, 63(3), pp.247-258

Lawrence R. (1983). Can America Compete? Washington: Brookings

Lawrence R.Z. (1983). “The Myth of U.S. Deindustrialization.” In: Challenge, 46(5), pp. 12-21

Lawrence R.Z. (1991). "Deindustrialization: Concepts and Evidence." Mimeo, Harvard University Press. Prepared for Ford Foundation-Columbia University conference on Deindustrialization, Nov. 15-16, 1991.

Legarda A. and Blazquez J. (2013). "Why Western Nations Need an Active Industrial Policy: An Analysis of Deindustrilaization and External Imbalances." ESADEgeo Position Paper 31, may 2013.

Available at: file:///C:/Users/Leif/Downloads/201305Deindustrialization_Legarda_Blazquez_EN.pdf

Lissoni F. (1996). “Deindustrialisation in Lombardy: an empirical assessment”. CESPRI Working Paper No.88, Milan.

Manning S., Massini S. and Lewin A. Y. (2008). "A Dynamic Perspective on Next-Generation Offshoring: The Global Sourcing of Science and Engineering Talent.“ In: Academy of Management Perspectives, 22(3), pp. 35-54.

Marin D. (2004). "A nation of poets and thinkers - less so with Eastern enlargement? Austria and Germany." CEPR Discussion Paper No. 4358.

Matsuyama K. (2008). "Structural Change." In: Durlauf S.N. and Blume L.E. (eds.), The New Palgrave Dictionary of Economics, 2 ed., Palgrave Macmillan.

Matsuyama K. (2009). "Structural Change in an Interdependent World: A Global View of Manufacturing Decline." In: Journal of the European Economic Association, 7(2-3), pp.478-486.

Matthews R.A., Maume M.O. and Miller W.J. (2001). “Deindustrialization, Economic Distress, and Homicide Rates in Midsized Rustbelt Cities." In: Homicide Studiesl, 5(2), pp.83-113

McKee G.A. (2008). The Problem of Jobs: Liberalism, Race, and Deindustrialization in Philadelphia. University of Chicago Press, $384 \mathrm{p}$.

McKinnon R. (2013). "The U.S. saving deficiency, current-account deficits, and deindustrialization: Implications for China." In: Journal of Policy Modeling, 35(3), pp. 449-458 
Mendels F.F. (1972). "Protoindustrialization. The first phase of the industrialization process." In: The Journal of Economic History, 32(1), pp. 241-261.

Meyer P. (2009). American Rust. Spiegel \& Grau, 368 pp.

Michaels G., Natraj A. and Van Reenen J. (2014) "Has ICT Polarized Skill Demand? Evidence from Eleven Countries over 25 years. The Review of Economics and Statistics, 96(1), pp.60-77.

Minchin T. (2006). "Just Like a Death: The Closing of the International Paper Company Mill in Mobile, Alabama, and the Deindustrialization of the South, 2000-2005." In: Alabama Review, 59(1), pp. 44-77

Mokyr J. (1999). "Editor's Introduction: The New Economic History and the Industrial Revolution." In: Mokyr J. (ed.), The British Industrial Revolution: an Economic Perspective. Boulder: Westview Press, $2^{\text {nd }}$ ed., pp. 1-127.

Naudé W., Szirmai A. and Lavopa A. (2013). "Industrialization lessons from BRICS: A comparative analysis." Institute for the Study of Labor (IZA), IZA Discussion Papers 7543.

Newman K. (1985). "Urban Anthropology and the Deindustrialization Paradigm." In: Urban Anthropology and Studies of Cultural Systems and World Economic Development, 14(1/3), pp. 5-19

Ngai L.R. and Petrongolo C. (2015). "Gender Gaps and the Rise of the Service Economy."

Available at: $\underline{\text { http://personal.Ise.ac.uk/petrongo/Ngai-Petrongolo2015.pdf }}$

Ngai L.R. and Pissarides C.A. (2004). "Structural Change in a Multi-Sector Model of Growth." Discussion Paper No. 4763, Centre for Economic Policy Research, London.

Ngai L.R. and Pissarides C.A. (2007). "Structural change in a multi-sector model of growth". In: American Economic Review, 97(1), pp.429-443.

Ngai L.R. and Pissarides C.A. (2008). “Trends in Hours and Economic Growth.” In: Review of Economic Dynamics, 11(2), pp.239256

Nickel S.J. (1981). “Biases in Dynamic Models with Fixed Effects.” In: Econometrica, 49(6), pp. 1417-1426

Nickell S., Redding S. and Swaffield J. (2008). “The uneven pace of deindustrialization in the OECD”. In: The World Economy, 31(9), pp.1154-1184.

Nordhaus W.D. (2005). "The Sources of the Productivity Rebound and the Manufacturing Employment Puzzle." Working paper no. 11354. National Bureau of Economic Research, Cambridge, Mass.

Nordhaus W.D. (2006). "Baumol's Diseases: A Macroeconomic Perspective.” Working paper no. 12218. National Bureau of Economic Research, Cambridge, Mass.

Olivetti C. and Petrongolo B. (2016). "The Evolution of Gender Gaps in Industrialized Countries." Prepared for the Annual Review of Economics, Vol. 8 (expected publication date September 2016).

Available at: http://personal.Ise.ac.uk/petrongo/Olivetti_Petrongolo_Jan2016_ALL.pdf

Ostry A.S., Barroetavena M., Hershler R., Kelly S., Demers P.A., Teschke K. and Hertzman D. (2002). "Effect of deindustrialisation on working conditions and self reported health in a sample of manufacturing firms." In: Journal of Epidemiology and Community Health, 56(7), pp. 506-509

Ousey G.C. (2000). “Deindustrialization, Female-Headed Families, and Black and White Juvenile Homicide Rates, 1970-1990." In: Sociological Inquiry, 70(4), pp. 391-419.

Pahl R. (1984). Divisions of Labour. Oxford: Blackwell

Palma G. (2008). "Deindustrialization, Premature Deindustrialization, and the Dutch Disease". In: Blume L. and Durlauf S. (eds.), The New Palgrave: A Dictionary of Economics, $2^{\text {nd }}$ edition. Basingstoke: Palgrave Macmillan, pp.401-410 
Palma J.G. (2014). "Deindustrialization, Premature Deindustrialization, and the Dutch Disease". In: Revista NECAT, Ano 3, n5 Jan-Jun de 2014, pp.7-23.

Pedroni P. (1995). "Panel Cointegration: Asymptotic and Finite Sample Properties of Pooled Time-series Tests with applications to the PPP hypothesis." In: Econometric Theory, 20(3), pp. 579-625.

Pedroni P. (1999). “Critical values for cointegration tests in heterogenous panels with multiple regressors." In: Oxford Bulletin of Economics and Statistics, Special Issue on Testing for Unit Roots and Cointegration using Panel Data, Theory and Applications, 61(S1), November, pp. 653-670.

Pesaran M.H. and Smith R.P. (1995). "Estimating Long-run relationships from Dynamic Heterogenous Panels." In: Journal of Econometrics, 68(1), pp. 79-113.

Pesaran M.H., Shin Y. and Smith R.P. (1997). "Estimating long-run relationships in dynamic heterogeneous panels." DAE Working Papers Amalgamated Series 9721.

Pesaran M.H., Shin Y. and Smith R.P. (1999). "Pooled Mean Group Estimation of Dynamic Heterogenous Panels.” In: Journal of the American Statistical Association, 94(446), pp. 621-634.

Phillips P.C.B. and Moon H.R. (1999). “Linear Regression Limit Theory for Nonstationary Panel Data.” In: Econometrica, 67(5), pp. 1057-1112.

Phillips P.C.B. and Moon H.R. (2000). "Nonstationary Panel Data Analysis: an overview of some recent developments." In: Econometric Reviews, 19(3), pp. 263-286.

Pierce J.R. and Schott P.K. (2014). "The Surprisingly Swift Decline of US Manufacturing Employment." CESifo Group Munich, CESifo Working Paper 4563.

Available at: $\underline{\text { http://www.cesifo-group.de/ifoHome/publications/working-papers/CESifoWP/CESifoWPdetails?wp id=19104020 }}$

Pieper U. (2000). "Deindustrialisation and the social and economic sustainability nexus in developing countries: Cross-country evidence on productivity and employment." In: Journal of Development Studies, 36(4), pp. 66-99.

Ray D. (2010). “Uneven Growth: A Framework for Research in Development Economics." In: Journal of Economic Perspectives, 24(3), pp. $45-60$

Reardon K.M. (2005). “Empowerment planning in East St. Louis, Illinois: A peoples' response to the deindustrialization blues." In: City: analysis of urban trends, culture, theory, policy, action, 9(1), pp. 85-100

Rendall M. (2014). "The Service Sector and Female Market Work." Centre for Institutions, policy and Culture in the Development Process, University of Zurich, Working Paper series, Working Paper No. 312.

Available at: http://www.econ.uzh.ch/ipcdp/Papers/ipcdp_wp312.pdf

Renner C. and Navarro V. (1989). "Why is our population of uninsured and underinsured persons growing? The consequences of the "Deindustrialization" of America." In: Annual Review of Public Health, 10, pp. 85-94

Robert-Nicoud F. (2008). "Offshoring of routine tasks and (de)industrialisation: Threat or opportunity-And for whom?" In: Journal of Urban Economics, 63(2), pp. 517-535

Rodrik D. (2015). "Premature Deindustrialization". IAS School of Social Sciences, Economics Working Papers, Paper No 107.

Rogerson R. (2008). "Structural Transformation and the Deterioration of European Labor Market Outcomes." In: Journal of Political Economy, 116(2), pp.235-259.

Rowthorn R. and Coutts K. (2004). "De-industrialisation and the Balance of Payments in Advanced Economies." In: Cambridge Journal of Economics, 28(5), pp. 767-90.

Rowthorn R. and Coutts K. (2013). "De-industrialisation and the Balance of Payments in Advanced Economies." Future of Manufacturing Project: Evidence Paper 31, Foresight, Government office for Science. 
Rowthorn R. and Ramaswamy R. (1997). "Deindustrialization: Causes and Implications." Pp. 61-77 in Staff Studies for the World Economic Outlook, by the Research Department of the International Monetary Fund. Washington, D.C.: International Monetary Fund.

Rowthorn R. and Ramaswamy R. (1999). "Growth, Trade, and Deindustrialization." In: International Monetary Fund Staff Papers, 46(1), pp. 18-41

Rowthorn R. and Wells J.R. (1987). De-industrialisation and Foreign Trade. Cambridge: Cambridge University Press

Saeger S.S. (1997). "Globalization and Deindustrialization: Myth and Reality in the OECD." In: Review of World Economics/Weltwirtschaftliches Archiv, 133(4), pp.579-608.

Samuelson P. (2004). "Where Ricardo and Mill Rebut and Confirm Arguments of Mainstream Economists Supporting Globalization." In: Journal of Economic Perspectives, 18(3), pp. 135-146

Schettkat R. and Yocarini L. (2006). "The shift to services employment: A review of the literature." In: Structural Change and Economic Dynamics, 17(2), pp.127-147

Schumpeter J. (1942). Capitalism, Socialism and Democracy. New York: Harper \& Row

Singelmann J. (1978). From Agriculture to services: Transformation to Industrial Employment. Sage Publications, Beverly Hills.

Sissons P. (2009). The longer-term labour market and community impacts of deindustrialization: a comparison of the Northumberland coalfield and the Monongahela Valley mill towns. University College London, PhD Human Geography.

Available at: http://discovery.ucl.ac.uk/15811/1/15811.pdf

Smith R.P. (2001). "Estimation and inference with non-stationary panel time-series data." Prepared for the RC33 Conference, Cologne, October.

Available at http://citeseerx.ist.psu.edu/viewdoc/download?doi=10.1.1.468.4264\&rep=rep1\&type=pdf

Smith R.P. and Fuertes A.-M. (2016). "Panel Time-Series."

Available at: http://www.bbk.ac.uk/ems/faculty/smith/ron-smith-downloads/RSpanel.pdf

Spayd D. and Dye C. (1991). "Deindustrialization and the Financial Support of Public Education." Paper presented at the Annual Meeting of the Mid-Western Educational Research Association (Chicago, IL, October 1991).

Stijepic D. (2011). Structural Change and Economic Growth: Analysis within the "Partially Balanced Growth-Framework. Dissertation, Fernuniversität in Hagen.

Available at: http://deposit.fernuni-hagen.de/2763/

Stijepic D. and Wagner H. (2008). “Dynamic Effects of Offshoring.” FernUniversität in Hagen, Discussion Paper N0. 427.

Available at: https://www.fernuni-hagen.de/wirtschaftswissenschaft/download/beitraege/db427.pdf

Stijepic D. and Wagner H. (2012). "Impacts of Intermediate Trade on Structural Change."

Available at: $\underline{\text { http://papers.ssrn.com/sol3/papers.cfm?abstract id=2134961 }}$

Strangleman T. and Rhodes J. (2014). "The 'New' Sociology of Deindustrialisation? Understanding Industrial Change." In: Sociology Compass, 8/4, pp.411-421

Strangleman T. (2016a). "Deindustrialization and the Historical Sociological Imagination: Making sense of Work and Industrial Change". In: Sociology 0038038515622906, first published on February 2, 2016 doi: 10.1177/00380385515622906

Strangleman T. (2016b). "Portrait of a deindustrialising island: Ray Pahl and industrial loss on Sheppey." In: Crow G. (ed.), Revisiting Divisions of Labour: The Impacts and Legacies of a Modern Sociological Classic, Manchester: Manchester University Press 
Szirmai A. (2012). "Industrialization as an engine of growth in developing countries, 1950-2005". In: Structural Change and Economic Dynamics, 23(4), pp.406-420

Szirmai A. and Verspagen B. (2011). "Manufacturing and economic growth in developing countries, 1950-2005." United Nations University - Maastricht Economic and Social Research Institute on Innovation and Technology, Working Paper 2011069

Taylor S. (1981). “De-industrialisation and unemployment in the west Midlands". In: The Political Quarterly, 52(1), pp.64-73

Thompson G., Murray T. and Jomini P. (2012). "Trade, Employment and Structural Change: The Australian Experience." In: Lippoldt D. (Ed.), Policy Priorities for International Trade and Jobs, Chapter 3, pp. 113-144

Tregenna F. (2013). "Manufacturing productivity, deindustrialization and reindustrialisation." In: Alcorta L., Naudé W. and Szirmai A. (eds.), Pathways to Industrialization in the 21st Century: New Challenges and Emerging Paradigms, Oxford: Oxford University Press.

Tregenna F. (2015). "Deindustrialization, structural change and sustainable economic growth." Research, Statistics and Industrial Policy Branch, Working Paper 2/2015.

Available at: http://www.unido.org//fileadmin/user_media/Services/PSD/WP_2015_02_v2.pdf

United Nations Industrial Development Organisation (2013). Industrial Development Report. UNIDO: Vienna.

Uy T., Yi K.-M. and Zhang J. (2013). “Structural change in an open economy.” In: Journal of Monetary Economics, 60(6), pp.667682.

Van Neuss L. (2015). "Why Did the Industrial Revolution Start in Britain?"

Available at SSRN: http://papers.ssrn.com/sol3/papers.cfm?abstract id=2696076

\section{Van Neuss L. (2016).}

\section{Available at SSRN}

Verley P. (1997). La révolution industrielle. Paris: Gallimard, 544 p.

Wallace D. and Wallace R. (1999). "Deindustrialization, Inner-City Decay, and the Hierarchical Diffusion of AIDS in the USA: How Neoloiberal and Cold War Policies Magnified the Ecological Niche for Emerging Infections and Created a National Security Crisis." In: Environment and Planning A, 31(1), pp. 113-139.

Webster D.F. (2010). Impacts of deindustrialization on the labour dmarket and beyond. PhD Thesis.

Available at: http://theses.gla.ac.uk/1720/1/2010websterphd.pdf.pdf

Weiss J. and Tribe M.A. (Eds.) (2016). Routledge Handbook of Inustry and Development. Abingdon, Oxon: Routledge, 446 p.

Weiss J. and Jalilian H. (2016). "Manufacturing as an engine of growth.” In: Weiss J. and Tribe M.A. (Eds.), Routledge Handbook of Inustry and Development. Abingdon, Oxon: Routledge, Chapter 2, pp. 26

Westerlund J. (2007). "Testing for Error Correction in Panel Data." In: Oxford Bulletin of Economics and Statistics, 69(6), pp. 709-748.

Whitford J. (2005). The New Old Economy: Networks, Institutions, and the Organizational Transformation of American Manufacturing. Oxford: Oxford University Press.

Wood A. (1994). North-South Trade, Employment, and Inequality: Changing Fortunes in a Skill-Driven World. Oxford: Clarendon Press.

Wood A. (1995). “How Trade Hurt Unskilled Workers.” In: Journal of Economic Perspectives, 3(3), pp.57-80 


\section{Appendix 1}

Table 1: Share of Manufacturing in Total Nominal Value Added (\%)

\begin{tabular}{|l|c|c|c|c|c|c|}
\cline { 2 - 6 } \multicolumn{1}{c|}{} & 1970 & 1980 & 1990 & 2000 & 200758 & $\begin{array}{c}\text { variation } \\
\text { (1970-2007) }\end{array}$ \\
\hline Australia & $24,6 \%$ & $19,8 \%$ & $14,5 \%$ & $12,7 \%$ & $10,5 \%$ & $-14,0 \%$ \\
\hline Austria & $27,9 \%$ & $23,7 \%$ & $21,4 \%$ & $20,3 \%$ & $20,0 \%$ & $-7,9 \%$ \\
\hline Belgium & $29,4 \%$ & $23,1 \%$ & $22,8 \%$ & $19,3 \%$ & $16,4 \%$ & $-13,0 \%$ \\
\hline Denmark & $20,5 \%$ & $18,9 \%$ & $17,4 \%$ & $16,2 \%$ & $15,0 \%$ & $-5,5 \%$ \\
\hline Finland & $26,2 \%$ & $27,5 \%$ & $22,6 \%$ & $26,2 \%$ & $23,6 \%$ & $-2,6 \%$ \\
\hline France & $24,4 \%$ & $21,7 \%$ & $18,3 \%$ & $16,0 \%$ & $12,3 \%$ & $-12,1 \%$ \\
\hline Germany & $34,9 \%$ & $29,7 \%$ & $28,1 \%$ & $22,9 \%$ & $23,6 \%$ & $-11,3 \%$ \\
\hline Greece & $23,1 \%$ & $22,2 \%$ & $18,1 \%$ & $12,0 \%$ & $11,1 \%$ & $-11,9 \%$ \\
\hline Ireland & $22,1 \%$ & $21,6 \%$ & $27,7 \%$ & $33,6 \%$ & $22,2 \%$ & $0,2 \%$ \\
\hline Italy & $27,6 \%$ & $28,9 \%$ & $23,3 \%$ & $21,0 \%$ & $19,0 \%$ & $-8,5 \%$ \\
\hline Japan & $33,5 \%$ & $27,2 \%$ & $26,1 \%$ & $21,3 \%$ & $20,6 \%$ & $-12,9 \%$ \\
\hline Luxembourg & $41,1 \%$ & $25,4 \%$ & $20,7 \%$ & $11,3 \%$ & $8,6 \%$ & $-32,5 \%$ \\
\hline Netherlands & $25,3 \%$ & $18,1 \%$ & $18,6 \%$ & $15,6 \%$ & $13,7 \%$ & $-11,6 \%$ \\
\hline Portugal & $16,8 \%$ & $20,6 \%$ & $19,2 \%$ & $17,1 \%$ & $14,4 \%$ & $-2,3 \%$ \\
\hline Spain & $30,5 \%$ & $28,1 \%$ & $23,6 \%$ & $18,6 \%$ & $14,9 \%$ & $-15,6 \%$ \\
\hline Sweden & $23,2 \%$ & $21,7 \%$ & $20,3 \%$ & $22,0 \%$ & $20,0 \%$ & $-3,2 \%$ \\
\hline United Kingdom & $34,2 \%$ & $26,8 \%$ & $22,8 \%$ & $17,3 \%$ & $12,4 \%$ & $-21,7 \%$ \\
\hline United States & $23,5 \%$ & $20,8 \%$ & $17,5 \%$ & $15,2 \%$ & $13,2 \%$ & $-10,4 \%$ \\
\hline EU15 & $26,6 \%$ & $23,4 \%$ & $22,6 \%$ & $19,9 \%$ & $18,2 \%$ & $-8,4 \%$ \\
\hline
\end{tabular}

Table 2: Share of Manufacturing in Total Employment (\%)

\begin{tabular}{|l|c|c|c|c|c|c|}
\cline { 2 - 6 } \multicolumn{1}{c|}{} & 1970 & 1980 & 1990 & 2000 & 2007 & \begin{tabular}{c} 
variation \\
\multicolumn{1}{c|}{}
\end{tabular} \\
\cline { 2 - 7 } \multicolumn{1}{c|}{} & $27,0 \%$ & $21,0 \%$ & $15,7 \%-2007)$ \\
\hline Australia & $26,3 \%$ & $25,0 \%$ & $21,5 \%$ & $13,5 \%$ & $10,9 \%$ & $-16,1 \%$ \\
\hline Austria & $31,9 \%$ & $25,5 \%$ & $22,0 \%$ & $17,3 \%$ & $14,5 \%$ & $-10,8 \%$ \\
\hline Belgium & $24,8 \%$ & $19,7 \%$ & $18,9 \%$ & $17,0 \%$ & $13,8 \%$ & $-17,4 \%$ \\
\hline Denmark & $21,6 \%$ & $23,1 \%$ & $18,9 \%$ & $18,7 \%$ & $16,7 \%$ & $-10,9 \%$ \\
\hline Finland & $23,4 \%$ & $22,1 \%$ & $18,5 \%$ & $15,3 \%$ & $12,9 \%$ & $-5,0 \%$ \\
\hline France & $33,9 \%$ & $29,6 \%$ & $26,7 \%$ & $20,9 \%$ & $19,3 \%$ & $-10,6 \%$ \\
\hline Germany & $20,4 \%$ & $23,0 \%$ & $22,1 \%$ & $16,2 \%$ & $13,9 \%$ & $-14,6 \%$ \\
\hline Greece & $20,5 \%$ & $21,6 \%$ & $19,7 \%$ & $18,3 \%$ & $13,7 \%$ & $-6,6 \%$ \\
\hline Ireland & $27,4 \%$ & $27,9 \%$ & $23,6 \%$ & $20,8 \%$ & $19,2 \%$ & $-6,8 \%$ \\
\hline Italy & $26,3 \%$ & $23,5 \%$ & $23,9 \%$ & $20,1 \%$ & $18,9 \%$ & $-8,2 \%$ \\
\hline Japan & $24,0 \%$ & $24,0 \%$ & $20,7 \%$ & $13,2 \%$ & $11,2 \%$ & $-7,5 \%$ \\
\hline Luxembourg & $24,8 \%$ & $20,4 \%$ & $17,8 \%$ & $14,0 \%$ & $12,0 \%$ & $-12,8 \%$ \\
\hline Netherlands & $22,1 \%$ & $23,4 \%$ & $23,2 \%$ & $20,2 \%$ & $17,6 \%$ & $-12,7 \%$ \\
\hline Portugal & $21,9 \%$ & $22,7 \%$ & $19,6 \%$ & $18,2 \%$ & $14,8 \%$ & $-4,6 \%$ \\
\hline Spain & $27,1 \%$ & $23,5 \%$ & $20,4 \%$ & $19,6 \%$ & $17,3 \%$ & $-7,0 \%$ \\
\hline Sweden & $33,2 \%$ & $27,5 \%$ & $20,3 \%$ & $16,7 \%$ & $11,8 \%$ & $-9,8 \%$ \\
\hline United Kingdom & $22,4 \%$ & $19,1 \%$ & $14,9 \%$ & $12,7 \%$ & $9,9 \%$ & $-21,4 \%$ \\
\hline United States & $28,3 \%$ & $25,8 \%$ & $22,0 \%$ & $18,3 \%$ & $15,6 \%$ & $-12,5 \%$ \\
\hline EU15 & & & & $-12,7 \%$ \\
\hline
\end{tabular}

Source: EUKLEMS Database

${ }^{58}$ As data on employment and value added are missing for Portugal for 2007, data for Portugal are related to the year 2006. 


\section{Appendix 2}

Table 1: Average Annual Growth Rate of Real Value Added and Employment, 1970-200759

\begin{tabular}{|l|c|c|c|c|}
\cline { 2 - 5 } \multicolumn{1}{c|}{} & \multicolumn{2}{c|}{ Value Added } & \multicolumn{2}{c|}{ Employment } \\
\cline { 2 - 5 } \multicolumn{1}{c|}{} & Total Economy & Manufacturing & Total Economy & Manufacturing \\
\hline Australia & $3,3 \%$ & $1,5 \%$ & $1,7 \%$ & $-0,9 \%$ \\
\hline Austria & $2,7 \%$ & $3,1 \%$ & $0,3 \%$ & $-0,8 \%$ \\
\hline Belgium & $2,4 \%$ & $2,7 \%$ & $0,4 \%$ & $-1,8 \%$ \\
\hline Denmark & $1,9 \%$ & $1,0 \%$ & $0,5 \%$ & $-1,3 \%$ \\
\hline Finland & $2,8 \%$ & $4,4 \%$ & $0,3 \%$ & $-0,5 \%$ \\
\hline France & $2,5 \%$ & $1,9 \%$ & $0,6 \%$ & $-1,3 \%$ \\
\hline Germany & $2,2 \%$ & $1,4 \%$ & $0,5 \%$ & $-1,2 \%$ \\
\hline Greece & $3,0 \%$ & $1,4 \%$ & $0,8 \%$ & $-0,2 \%$ \\
\hline Ireland & $4,9 \%$ & $7,1 \%$ & $1,9 \%$ & $0,6 \%$ \\
\hline Italy & $2,3 \%$ & $2,5 \%$ & $0,6 \%$ & $-0,2 \%$ \\
\hline Japan & $3,2 \%$ & $3,9 \%$ & $0,5 \%$ & $-0,6 \%$ \\
\hline Luxembourg & $5,0 \%$ & $1,8 \%$ & $2,4 \%$ & $-0,6 \%$ \\
\hline Netherlands & $2,7 \%$ & $2,4 \%$ & $1,2 \%$ & $-0,9 \%$ \\
\hline Portugal & $3,2 \%$ & $2,4 \%$ & $0,4 \%$ & $-0,3 \%$ \\
\hline Spain & $3,1 \%$ & $2,8 \%$ & $1,4 \%$ & $0,3 \%$ \\
\hline Sweden & $2,3 \%$ & $3,2 \%$ & $0,3 \%$ & $-1,2 \%$ \\
\hline United Kingdom & $2,1 \%$ & $0,6 \%$ & $1,6 \%$ & $-2,5 \%$ \\
\hline United States & $2,9 \%$ & $2,8 \%$ & $0,6 \%$ & $-0,7 \%$ \\
\hline EU15 & $2,5 \%$ & $1,9 \%$ & $-1,0 \%$ \\
\hline
\end{tabular}

Source: EUKLEMS Database

${ }^{59}$ As data on employment and value added are missing for Portugal for 2007, the period covered for Portufal is 1970-2006. 


\section{Appendix 3}

Table 1: Average Annual Growth Rate of Real Value Added, 1970-2007

\begin{tabular}{|l|c|c|c|c|c|c|c|c|}
\cline { 2 - 9 } & \multicolumn{2}{c|}{$1970-1980$} & \multicolumn{2}{c|}{$1980-1990$} & \multicolumn{2}{c|}{$1990-2000$} & \multicolumn{2}{c|}{$2000-200760$} \\
\cline { 2 - 9 } \multicolumn{1}{l|}{} & Economy & Manufact. & Economy & Manufact. & \multirow{2}{*}{ Economy } & Manufact. & \multirow{2}{*}{ Economy } & Manufact. \\
\hline Australia & $3,0 \%$ & $1,5 \%$ & $3,3 \%$ & $1,2 \%$ & $3,6 \%$ & $1,8 \%$ & $3,2 \%$ & $1,6 \%$ \\
\hline Austria & $3,7 \%$ & $3,6 \%$ & $2,2 \%$ & $2,5 \%$ & $2,6 \%$ & $2,8 \%$ & $2,1 \%$ & $3,5 \%$ \\
\hline Belgium & $3,6 \%$ & $4,5 \%$ & $2,0 \%$ & $3,4 \%$ & $2,0 \%$ & $1,4 \%$ & $1,9 \%$ & $1,0 \%$ \\
\hline Denmark & $2,1 \%$ & $1,6 \%$ & $1,9 \%$ & $0,4 \%$ & $2,3 \%$ & $1,2 \%$ & $1,3 \%$ & $0,6 \%$ \\
\hline Finland & $3,5 \%$ & $3,8 \%$ & $3,0 \%$ & $3,6 \%$ & $2,0 \%$ & $5,0 \%$ & $2,9 \%$ & $5,5 \%$ \\
\hline France & $3,5 \%$ & $3,5 \%$ & $2,4 \%$ & $0,7 \%$ & $1,9 \%$ & $2,3 \%$ & $1,8 \%$ & $0,8 \%$ \\
\hline Germany & $2,8 \%$ & $1,9 \%$ & $2,3 \%$ & $1,6 \%$ & $2,0 \%$ & $0,2 \%$ & $1,4 \%$ & $2,0 \%$ \\
\hline Greece & $5,0 \%$ & $5,9 \%$ & $1,4 \%$ & $-0,5 \%$ & $2,0 \%$ & $-0,9 \%$ & $3,8 \%$ & $0,9 \%$ \\
\hline Ireland & $4,0 \%$ & $4,5 \%$ & $3,6 \%$ & $8,0 \%$ & $6,7 \%$ & $10,2 \%$ & $5,6 \%$ & $5,0 \%$ \\
\hline Italy & $3,8 \%$ & $6,1 \%$ & $2,4 \%$ & $2,1 \%$ & $1,5 \%$ & $1,1 \%$ & $1,2 \%$ & $0,1 \%$ \\
\hline Japan & $5,1 \%$ & $5,5 \%$ & $4,6 \%$ & $6,1 \%$ & $1,4 \%$ & $1,1 \%$ & $1,3 \%$ & $2,4 \%$ \\
\hline Luxembourg & $3,3 \%$ & $-1,6 \%$ & $7,2 \%$ & $5,5 \%$ & $5,0 \%$ & $2,7 \%$ & $4,3 \%$ & $0,1 \%$ \\
\hline Netherlands & $3,5 \%$ & $2,9 \%$ & $2,3 \%$ & $2,5 \%$ & $3,0 \%$ & $2,6 \%$ & $1,9 \%$ & $1,4 \%$ \\
\hline Portugal & $5,0 \%$ & $5,5 \%$ & $3,0 \%$ & $1,6 \%$ & $2,7 \%$ & $1,6 \%$ & $1,1 \%$ & $0,2 \%$ \\
\hline Spain & $3,5 \%$ & $4,6 \%$ & $2,9 \%$ & $2,7 \%$ & $2,8 \%$ & $2,1 \%$ & $3,3 \%$ & $1,3 \%$ \\
\hline Sweden & $2,3 \%$ & $1,5 \%$ & $2,3 \%$ & $1,9 \%$ & $2,1 \%$ & $5,1 \%$ & $2,8 \%$ & $4,5 \%$ \\
\hline United Kingdom & $1,0 \%$ & $-0,6 \%$ & $2,5 \%$ & $2,0 \%$ & $2,5 \%$ & $0,6 \%$ & $2,4 \%$ & $0,5 \%$ \\
\hline United States & $2,7 \%$ & $2,2 \%$ & $3,1 \%$ & $2,9 \%$ & $3,2 \%$ & $4,1 \%$ & $2,3 \%$ & $1,6 \%$ \\
\hline EU15 & $2,9 \%$ & $2,6 \%$ & $2,5 \%$ & $1,9 \%$ & $2,2 \%$ & $1,4 \%$ & $2,1 \%$ & $1,4 \%$ \\
\hline
\end{tabular}

Table 2: Average Annual Growth Rate of Employment, 1970-2007

\begin{tabular}{|l|c|c|c|c|c|c|c|c|}
\cline { 2 - 8 } \multicolumn{1}{c|}{} & \multicolumn{2}{c}{$1970-1980$} & \multicolumn{2}{c|}{$1980-1990$} & \multicolumn{2}{c|}{$1990-2000$} & \multicolumn{2}{c|}{$2000-2007$} \\
\cline { 2 - 9 } \multicolumn{1}{c|}{} & Economy & Manufact. & Economy & Manufact. & Economy & Manufact. & Economy & Manufact. \\
\hline Australia & $1,4 \%$ & $-1,2 \%$ & $1,8 \%$ & $-1,4 \%$ & $1,5 \%$ & $-0,3 \%$ & $2,3 \%$ & $-0,8 \%$ \\
\hline Austria & $-0,1 \%$ & $0,1 \%$ & $0,2 \%$ & $-1,3 \%$ & $0,6 \%$ & $-1,3 \%$ & $0,6 \%$ & $-0,4 \%$ \\
\hline Belgium & $0,2 \%$ & $-2,2 \%$ & $0,2 \%$ & $-1,6 \%$ & $0,6 \%$ & $-1,6 \%$ & $0,9 \%$ & $-1,5 \%$ \\
\hline Denmark & $0,4 \%$ & $-2,0 \%$ & $0,4 \%$ & $-0,2 \%$ & $0,4 \%$ & $-1,2 \%$ & $0,7 \%$ & $-1,7 \%$ \\
\hline Finland & $0,4 \%$ & $1,1 \%$ & $0,5 \%$ & $-1,4 \%$ & $-0,8 \%$ & $-0,9 \%$ & $1,2 \%$ & $-0,7 \%$ \\
\hline France & $0,6 \%$ & $-0,3 \%$ & $0,3 \%$ & $-1,8 \%$ & $0,6 \%$ & $-1,4 \%$ & $0,8 \%$ & $-1,6 \%$ \\
\hline Germany & $0,3 \%$ & $-1,1 \%$ & $1,0 \%$ & $0,0 \%$ & $0,4 \%$ & $-2,5 \%$ & $0,2 \%$ & $-1,0 \%$ \\
\hline Greece & $1,0 \%$ & $2,3 \%$ & $0,9 \%$ & $0,5 \%$ & $0,5 \%$ & $-2,5 \%$ & $1,0 \%$ & $-1,3 \%$ \\
\hline Ireland & $1,0 \%$ & $1,3 \%$ & $0,3 \%$ & $-0,9 \%$ & $3,4 \%$ & $2,4 \%$ & $3,3 \%$ & $-1,1 \%$ \\
\hline Italy & $0,7 \%$ & $1,2 \%$ & $0,6 \%$ & $-1,1 \%$ & $0,1 \%$ & $-1,1 \%$ & $1,3 \%$ & $0,2 \%$ \\
\hline Japan & $0,8 \%$ & $-0,3 \%$ & $0,9 \%$ & $0,9 \%$ & $0,2 \%$ & $-1,8 \%$ & $-0,2 \%$ & $-1,5 \%$ \\
\hline Luxembourg & $1,3 \%$ & $-1,0 \%$ & $1,7 \%$ & $-0,8 \%$ & $3,4 \%$ & $-1,1 \%$ & $3,4 \%$ & $0,9 \%$ \\
\hline Netherlands & $0,6 \%$ & $-1,4 \%$ & $1,5 \%$ & $-0,2 \%$ & $1,9 \%$ & $-0,6 \%$ & $0,9 \%$ & $-1,7 \%$ \\
\hline Portugal & $1,6 \%$ & $2,2 \%$ & $-1,0 \%$ & $-1,2 \%$ & $0,6 \%$ & $-0,8 \%$ & $0,3 \%$ & $-2,0 \%$ \\
\hline Spain & $0,0 \%$ & $0,4 \%$ & $1,1 \%$ & $-0,5 \%$ & $1,7 \%$ & $0,9 \%$ & $3,3 \%$ & $0,6 \%$ \\
\hline Sweden & $0,9 \%$ & $-0,8 \%$ & $0,5 \%$ & $-1,0 \%$ & $-0,7 \%$ & $-1,6 \%$ & $0,7 \%$ & $-1,4 \%$ \\
\hline United Kingdom & $0,3 \%$ & $-1,8 \%$ & $0,4 \%$ & $-2,8 \%$ & $0,3 \%$ & $-1,8 \%$ & $0,9 \%$ & $-3,9 \%$ \\
\hline United States & $2,1 \%$ & $0,5 \%$ & $1,8 \%$ & $-0,5 \%$ & $1,5 \%$ & $-0,1 \%$ & $0,6 \%$ & $-3,6 \%$ \\
\hline EU15 & $0,5 \%$ & $-0,5 \%$ & $0,6 \%$ & $-1,1 \%$ & $0,6 \%$ & $-1,5 \%$ & $1,0 \%$ & $-1,2 \%$ \\
\hline
\end{tabular}

Source: EUKLEMS Database

${ }^{60}$ As data on employment and value added are missing for Portugal for 2007, the period covered for Portufal is 2000-2006. 


\section{Appendix 4}

Table 1: Average Annual Growth Rate of Labor Productivity and Prices, 1970-200761

\begin{tabular}{|l|c|c|c|c|c|c|}
\cline { 2 - 7 } \multicolumn{1}{c|}{} & \multicolumn{3}{c}{ Labor Productivity } & \multicolumn{2}{c|}{ Prices } \\
\cline { 2 - 7 } \multicolumn{1}{c|}{} & Manufacturing & Services & Differential & Manufacturing & Services & Differential \\
\hline Australia & $2,4 \%$ & $1,3 \%$ & $1,1 \%$ & $5,4 \%$ & $6,1 \%$ & $-0,8 \%$ \\
\hline Austria & $4,3 \%$ & $1,6 \%$ & $2,8 \%$ & $2,1 \%$ & $4,0 \%$ & $-1,9 \%$ \\
\hline Belgium & $4,9 \%$ & $1,7 \%$ & $3,2 \%$ & $2,1 \%$ & $4,8 \%$ & $-2,7 \%$ \\
\hline Canada & $2,6 \%$ & $1,1 \%$ & $1,5 \%$ & $4,0 \%$ & $4,7 \%$ & $-0,7 \%$ \\
\hline Denmark & $2,5 \%$ & $1,4 \%$ & $1,1 \%$ & $5,3 \%$ & $5,2 \%$ & $0,0 \%$ \\
\hline Finland & $5,3 \%$ & $1,6 \%$ & $3,7 \%$ & $3,8 \%$ & $6,4 \%$ & $-2,6 \%$ \\
\hline France & $3,7 \%$ & $1,8 \%$ & $1,9 \%$ & $3,8 \%$ & $5,5 \%$ & $-1,8 \%$ \\
\hline Germany & $3,2 \%$ & $2,2 \%$ & $1,1 \%$ & $2,5 \%$ & $2,9 \%$ & $-0,4 \%$ \\
\hline Greece & $1,4 \%$ & $1,0 \%$ & $0,5 \%$ & $11,0 \%$ & $11,5 \%$ & $-0,5 \%$ \\
\hline Ireland & $6,7 \%$ & $1,9 \%$ & $4,8 \%$ & $5,3 \%$ & $8,7 \%$ & $-3,4 \%$ \\
\hline Italy & $2,9 \%$ & $0,5 \%$ & $2,4 \%$ & $6,9 \%$ & $8,8 \%$ & $-2,0 \%$ \\
\hline Japan & $4,9 \%$ & $2,7 \%$ & $2,2 \%$ & $0,2 \%$ & $2,6 \%$ & $-2,4 \%$ \\
\hline Luxembourg & $1,6 \%$ & $3,7 \%$ & $-2,2 \%$ & $2,7 \%$ & $4,1 \%$ & $-1,4 \%$ \\
\hline Netherlands & $3,9 \%$ & $1,8 \%$ & $2,1 \%$ & $2,0 \%$ & $3,8 \%$ & $-1,8 \%$ \\
\hline Norway & $2,1 \%$ & $2,2 \%$ & $-0,1 \%$ & $5,9 \%$ & $5,1 \%$ & $0,8 \%$ \\
\hline Portugal & $3,1 \%$ & $2,8 \%$ & $0,3 \%$ & $10,3 \%$ & $9,9 \%$ & $0,4 \%$ \\
\hline Spain & $2,9 \%$ & $1,0 \%$ & $1,9 \%$ & $6,5 \%$ & $9,1 \%$ & $-2,7 \%$ \\
\hline Sweden & $4,0 \%$ & $1,1 \%$ & $2,9 \%$ & $4,3 \%$ & $6,0 \%$ & $-1,8 \%$ \\
\hline United Kingdom & $3,2 \%$ & $1,4 \%$ & $1,8 \%$ & $5,6 \%$ & $7,4 \%$ & $-1,8 \%$ \\
\hline United States & $3,5 \%$ & $1,0 \%$ & $2,5 \%$ & $2,6 \%$ & $4,5 \%$ & $-1,8 \%$ \\
\hline EU15 & $3,3 \%$ & $1,5 \%$ & $1,7 \%$ & $2,2 \%$ & $2,9 \%$ & $-0,7 \%$ \\
\hline
\end{tabular}

Source: EUKlems Database, STAN Database (OCDE) ${ }^{62}$

${ }^{61}$ As data on employment and value added are missing for Portugal for 2007, the period covered for Portufal is 1970-2006

62 Data for Canada and Norway are from the STAN Database. For the other countries, data are from the EU Klems Database. 


\section{Appendix 5}

Table 1: Share of Finance, Real Estate and PBS in Total Employment, $1970^{63}$ and $2007^{64}$

\begin{tabular}{|l|c|c|}
\cline { 2 - 3 } \multicolumn{1}{c|}{} & $\begin{array}{c}\text { Share of total employment } \\
\text { in 1970 (\%) }\end{array}$ & $\begin{array}{c}\text { Share of total employment } \\
\text { in 2007 (\%) }\end{array}$ \\
\hline Australia & $6,5 \%$ & $16,5 \%$ \\
\hline Austria & $4,6 \%$ & $15,9 \%$ \\
\hline Belgium & $6,6 \%$ & $20,4 \%$ \\
\hline Canada & $7,0 \%$ & $17,8 \%$ \\
\hline Denmark & $6,7 \%$ & $15,9 \%$ \\
\hline Finland & $3,6 \%$ & $12,7 \%$ \\
\hline France & $7,6 \%$ & $18,5 \%$ \\
\hline Germany & $5,7 \%$ & $17,2 \%$ \\
\hline Greece & $3,6 \%$ & $10,1 \%$ \\
\hline Ireland & $3,4 \%$ & $13,9 \%$ \\
\hline Italy & $2,9 \%$ & $14,2 \%$ \\
\hline Japan & $5,0 \%$ & $14,7 \%$ \\
\hline Luxembourg & $11,4 \%$ & $27,6 \%$ \\
\hline Netherlands & $9,0 \%$ & $22,2 \%$ \\
\hline Norway & $4,3 \%$ & $14,0 \%$ \\
\hline Portugal & $2,9 \%$ & $7,4 \%$ \\
\hline Spain & $3,4 \%$ & $11,4 \%$ \\
\hline Sweden & $5,1 \%$ & $14,5 \%$ \\
\hline United Kingdom & $8,1 \%$ & $22,3 \%$ \\
\hline United States & $10,6 \%$ & $19,6 \%$ \\
\hline EU15 & $5,8 \%$ & $16,6 \%$ \\
\hline
\end{tabular}

Table 2: Evolution of Employment in Total Economy and Finance, Real Estate and PBS, $1970-2007^{65}$

\begin{tabular}{|c|c|c|c|c|c|}
\hline & \multicolumn{3}{|c|}{ Total Economy } & \multicolumn{2}{|c|}{ Finance, Real Estate and PBS } \\
\hline & $\begin{array}{l}\text { Growth Rate of } \\
\text { Employment, } \\
\text { 1970-2007 (\%) }\end{array}$ & $\begin{array}{l}\text { Average Annual } \\
\text { Growth Rate of } \\
\text { Employment, } \\
1970-2007 \text { (\%) }\end{array}$ & $\begin{array}{c}\text { Growth Rate of } \\
\text { Employment, } \\
\text { 1970-2007 (\%) }\end{array}$ & $\begin{array}{c}\text { Average Annual } \\
\text { Growth Rate of } \\
\text { Employment, } \\
\text { 1970-2007 (\%) }\end{array}$ & $\begin{array}{c}\text { Contribution to } \\
\text { Employment Growth } \\
\text { of Total Economy, } \\
1970-2007(\%)\end{array}$ \\
\hline Australia & $77,4 \%$ & $1,6 \%$ & $348,3 \%$ & $4,1 \%$ & $22,7 \%$ \\
\hline Austria & $5,7 \%$ & $0,1 \%$ & $261,5 \%$ & $3,5 \%$ & $12,1 \%$ \\
\hline Belgium & $-3,7 \%$ & $-0,1 \%$ & $196,6 \%$ & $3,0 \%$ & $13,0 \%$ \\
\hline Canada & $86,7 \%$ & $1,7 \%$ & $376,9 \%$ & $4,3 \%$ & $26,3 \%$ \\
\hline Denmark & $-0,5 \%$ & $0,0 \%$ & $137,6 \%$ & $2,4 \%$ & $9,2 \%$ \\
\hline Finland & $-5,8 \%$ & $-0,2 \%$ & $232,3 \%$ & $3,3 \%$ & $8,4 \%$ \\
\hline France & $-7,0 \%$ & $-0,2 \%$ & $127,7 \%$ & $2,2 \%$ & $9,7 \%$ \\
\hline Germany & $-12,2 \%$ & $-0,4 \%$ & $162,3 \%$ & $2,6 \%$ & $9,3 \%$ \\
\hline Greece & $42,6 \%$ & $1,0 \%$ & $294,8 \%$ & $3,8 \%$ & $10,7 \%$ \\
\hline Ireland & $70,1 \%$ & $1,4 \%$ & $587,7 \%$ & $5,3 \%$ & $20,2 \%$ \\
\hline Italy & $25,0 \%$ & $0,6 \%$ & $513,9 \%$ & $5,0 \%$ & $14,8 \%$ \\
\hline Japan & $-3,0 \%$ & $-0,1 \%$ & $182,3 \%$ & $2,9 \%$ & $9,2 \%$ \\
\hline Luxembourg & $133,7 \%$ & $2,3 \%$ & $464,4 \%$ & $4,8 \%$ & $53,0 \%$ \\
\hline Netherlands & $19,8 \%$ & $0,5 \%$ & $196,9 \%$ & $3,0 \%$ & $17,6 \%$ \\
\hline Norway & $19,5 \%$ & $0,5 \%$ & $285,4 \%$ & $3,7 \%$ & $12,4 \%$ \\
\hline Portugal & $-0,7 \%$ & $0,0 \%$ & $153,5 \%$ & $2,6 \%$ & $4,5 \%$ \\
\hline Spain & $43,1 \%$ & $1,0 \%$ & $385,2 \%$ & $4,4 \%$ & $12,9 \%$ \\
\hline Sweden & $15,4 \%$ & $0,4 \%$ & $225,5 \%$ & $3,2 \%$ & $11,6 \%$ \\
\hline United Kingdom & $6,8 \%$ & $0,2 \%$ & $195,0 \%$ & $3,0 \%$ & $15,8 \%$ \\
\hline United States & $53,0 \%$ & $1,4 \%$ & $181,9 \%$ & $3,5 \%$ & $19,4 \%$ \\
\hline EU15 & $7,0 \%$ & $0,2 \%$ & $209,1 \%$ & $3,1 \%$ & $12,0 \%$ \\
\hline
\end{tabular}

Source: EUKlems Database, STAN Database (OCDE) 66

\footnotetext{
${ }^{63}$ As data is missing for the US before 1977, data for the US is related to the year 1977.

${ }^{64}$ As data is missing for Portugal for the year 2007, data for Portugal is related to the year 2006.

65 The period covered for the US is 1977-2007. The period covered for Portugal is 1970-2006.

${ }^{66}$ Data for Canada and Norway are from the STAN Database. For the other countries, data are from the EU Klems Database.
} 


\section{Appendix 6}

Table 1: Share of Professional and Business Services (PBS) in Total Employment, 197067 and 200768

\begin{tabular}{|l|c|c|}
\cline { 2 - 3 } \multicolumn{1}{c|}{} & $\begin{array}{c}\text { Share of } \\
\text { total employment } \\
\text { in 1970 (\%) }\end{array}$ & $\begin{array}{c}\text { Share of } \\
\text { total employment } \\
\text { in 2007 (\%) }\end{array}$ \\
\hline Australia & $3,2 \%$ & $10,9 \%$ \\
\hline Austria & $2,2 \%$ & $11,7 \%$ \\
\hline Belgium & $3,6 \%$ & $16,6 \%$ \\
\hline Denmark & $3,7 \%$ & $11,4 \%$ \\
\hline Finland & $1,4 \%$ & $9,5 \%$ \\
\hline France & $5,0 \%$ & $14,4 \%$ \\
\hline Germany & $3,0 \%$ & $12,9 \%$ \\
\hline Greece & $2,6 \%$ & $7,4 \%$ \\
\hline Ireland & $2,0 \%$ & $8,5 \%$ \\
\hline Italy & $1,7 \%$ & $11,6 \%$ \\
\hline Japan & $2,2 \%$ & $10,5 \%$ \\
\hline Luxembourg & $4,2 \%$ & $15,0 \%$ \\
\hline Netherlands & $5,7 \%$ & $17,6 \%$ \\
\hline Norway & $2,3 \%$ & $10,5 \%$ \\
\hline Portugal & $0,8 \%$ & $5,6 \%$ \\
\hline Spain & $1,6 \%$ & $8,2 \%$ \\
\hline Sweden & $3,1 \%$ & $10,7 \%$ \\
\hline United Kingdom & $5,3 \%$ & $16,8 \%$ \\
\hline United States & $5,6 \%$ & $13,8 \%$ \\
\hline EU15 & $3,4 \%$ & $12,7 \%$ \\
\hline & & \\
\hline
\end{tabular}

Table 2: Evolution of Employment in Professional and Business Services (PBS), 1970-2007 ${ }^{69}$

\begin{tabular}{|c|c|c|c|c|c|}
\hline & \multicolumn{2}{|c|}{ Total Economy } & \multicolumn{3}{|c|}{ PBS } \\
\hline & $\begin{array}{l}\text { Growth Rate of } \\
\text { Employment, } \\
1970-2007(\%)\end{array}$ & $\begin{array}{c}\text { Average Annual } \\
\text { Growth Rate of } \\
\text { Employment, } \\
\text { 1970-2007 (\%) }\end{array}$ & $\begin{array}{l}\text { Growth Rate of } \\
\text { Employment, } \\
1970-2007(\%)\end{array}$ & $\begin{array}{c}\text { Average Annual } \\
\text { Growth Rate of } \\
\text { Employment, } \\
\text { 1970-2007 (\%) }\end{array}$ & $\begin{array}{c}\text { Contribution to } \\
\text { Employment Growth } \\
\text { of Total Economy, } \\
1970-2007(\%)\end{array}$ \\
\hline Australia & $77,4 \%$ & $1,6 \%$ & $496,2 \%$ & $4,9 \%$ & $16,1 \%$ \\
\hline Austria & $5,7 \%$ & $0,1 \%$ & $467,0 \%$ & $4,8 \%$ & $10,2 \%$ \\
\hline Belgium & $-3,7 \%$ & $-0,1 \%$ & $342,8 \%$ & $4,1 \%$ & $12,4 \%$ \\
\hline Denmark & $-0,5 \%$ & $0,0 \%$ & $211,3 \%$ & $3,1 \%$ & $7,7 \%$ \\
\hline Finland & $-5,8 \%$ & $-0,2 \%$ & $564,5 \%$ & $5,3 \%$ & $7,6 \%$ \\
\hline France & $-7,0 \%$ & $-0,2 \%$ & $168,0 \%$ & $2,7 \%$ & $8,4 \%$ \\
\hline Germany & $-12,2 \%$ & $-0,4 \%$ & $271,8 \%$ & $3,6 \%$ & $8,3 \%$ \\
\hline Greece & $42,6 \%$ & $1,0 \%$ & $315,1 \%$ & $3,9 \%$ & $8,1 \%$ \\
\hline Ireland & $70,1 \%$ & $1,4 \%$ & $608,1 \%$ & $5,4 \%$ & $12,3 \%$ \\
\hline Italy & $25,0 \%$ & $0,6 \%$ & $762,5 \%$ & $6,0 \%$ & $12,8 \%$ \\
\hline Japan & $-3,0 \%$ & $-0,1 \%$ & $350,9 \%$ & $4,3 \%$ & $7,9 \%$ \\
\hline Luxembourg & $133,7 \%$ & $2,3 \%$ & $741,2 \%$ & $5,9 \%$ & $30,9 \%$ \\
\hline Netherlands & $19,8 \%$ & $0,5 \%$ & $267,5 \%$ & $3,6 \%$ & $15,3 \%$ \\
\hline Norway & $19,5 \%$ & $0,5 \%$ & $455,6 \%$ & $4,7 \%$ & $10,3 \%$ \\
\hline Portugal & $-0,7 \%$ & $0,0 \%$ & $567,0 \%$ & $5,4 \%$ & $4,7 \%$ \\
\hline Spain & $43,1 \%$ & $1,0 \%$ & $625,7 \%$ & $5,5 \%$ & $10,2 \%$ \\
\hline Sweden & $15,4 \%$ & $0,4 \%$ & $302,8 \%$ & $3,8 \%$ & $9,3 \%$ \\
\hline United Kingdom & $6,8 \%$ & $0,2 \%$ & $235,2 \%$ & $3,3 \%$ & $12,6 \%$ \\
\hline United States & $53,0 \%$ & $1,4 \%$ & $274,8 \%$ & $4,5 \%$ & $15,4 \%$ \\
\hline EU15 & $7,0 \%$ & $0,2 \%$ & $296,9 \%$ & $3,8 \%$ & $10,1 \%$ \\
\hline
\end{tabular}

Source: EUKlems Database, STAN Database $(\mathrm{OCDE})^{70}$

\footnotetext{
${ }^{67}$ As data is missing for the US before 1977, data for the US is related to the year 1977.

${ }^{68}$ As data is missing for Portugal for the year 2007, data for Portugal is related to the year 2006.

69 The period covered for the US is 1977-2007. The period covered for Portugal is 1970-2006.

70 Data for Canada and Norway are from the STAN Database. For the other countries, data are from the EU Klems Database.
} 


\section{Appendix 7}

Table 1: Ratio of Intermediate Consumption over Gross Output in Manufacturing

\begin{tabular}{|l|c|c|c|c|c|}
\cline { 2 - 5 } \multicolumn{1}{c|}{} & $1970^{71}$ & 1980 & 1990 & 2000 & $2007^{72}$ \\
\hline Australia & 0,62 & 0,67 & 0,65 & 0,70 & 0,71 \\
\hline Austria & 0,65 & 0,65 & 0,64 & 0,64 & 0,68 \\
\hline Belgium & 0,68 & 0,71 & 0,70 & 0,75 & 0,80 \\
\hline Canada & 0,64 & 0,69 & 0,66 & 0,68 & 0,70 \\
\hline Denmark & 0,66 & 0,68 & 0,66 & 0,65 & 0,67 \\
\hline Finland & 0,67 & 0,69 & 0,66 & 0,70 & 0,71 \\
\hline France & 0,70 & 0,71 & 0,70 & 0,73 & 0,76 \\
\hline Germany & 0,61 & 0,64 & 0,62 & 0,67 & 0,69 \\
\hline Greece & 0,63 & 0,64 & 0,65 & 0,67 & 0,65 \\
\hline Ireland & 0,65 & 0,65 & 0,65 & 0,68 & 0,67 \\
\hline Italy & 0,63 & 0,67 & 0,67 & 0,72 & 0,74 \\
\hline Japan & 0,68 & 0,71 & 0,66 & 0,64 & 0,68 \\
\hline Luxembourg & 0,68 & 0,68 & 0,64 & 0,68 & 0,73 \\
\hline Netherlands & 0,68 & 0,74 & 0,71 & 0,73 & 0,75 \\
\hline Norway & 0,68 & 0,72 & 0,73 & 0,71 & 0,74 \\
\hline Portugal & 0,74 & 0,76 & 0,77 & 0,73 & 0,75 \\
\hline Spain & 0,70 & 0,70 & 0,69 & 0,72 & 0,74 \\
\hline Sweden & 0,67 & 0,67 & 0,67 & 0,69 & 0,72 \\
\hline United Kingdom & 0,67 & 0,70 & 0,62 & 0,65 & 0,67 \\
\hline United States & 0,66 & 0,68 & 0,65 & 0,64 & 0,66 \\
\hline EU15 & 0,64 & 0,67 & 0,66 & 0,69 & 0,72 \\
\hline
\end{tabular}

Source: EUKlems Database, STAN Database (OCDE) ${ }^{73}$

${ }^{71}$ As data is missing for the US before 1977, data for the US is related to the year 1977.

72 As data is missing for Portugal for the year 2007, data for Portugal is related to the year 2006.

${ }^{73}$ Data for Canada and Norway are from the STAN Database. For the other countries, data are from the EU Klems Database. 


\section{Appendix 8}

Table 1: share of imports in domestic final demand for manufactures

\begin{tabular}{|l|c|c|c|}
\cline { 2 - 4 } \multicolumn{1}{c|}{} & 1995 & 2007 & 2011 \\
\hline Australia & $31,1 \%$ & $47,0 \%$ & $47,5 \%$ \\
\hline Austria & $46,5 \%$ & $67,5 \%$ & $68,1 \%$ \\
\hline Belgium & $72,0 \%$ & $79,4 \%$ & $83,4 \%$ \\
\hline Denmark & $67,8 \%$ & $80,8 \%$ & $84,4 \%$ \\
\hline Finland & $38,7 \%$ & $54,2 \%$ & $52,2 \%$ \\
\hline France & $36,6 \%$ & $47,6 \%$ & $48,2 \%$ \\
\hline Germany & $30,8 \%$ & $48,3 \%$ & $49,7 \%$ \\
\hline Greece & $32,8 \%$ & $49,8 \%$ & $45,4 \%$ \\
\hline Ireland & $68,9 \%$ & $73,9 \%$ & $58,8 \%$ \\
\hline Italy & $25,0 \%$ & $35,1 \%$ & $36,4 \%$ \\
\hline Japan & $12,1 \%$ & $23,0 \%$ & $22,6 \%$ \\
\hline Luxembourg & $88,8 \%$ & $91,0 \%$ & $93,4 \%$ \\
\hline Netherlands & $63,7 \%$ & $71,8 \%$ & $77,6 \%$ \\
\hline Portugal & $40,2 \%$ & $56,5 \%$ & $52,1 \%$ \\
\hline Spain & $28,9 \%$ & $50,9 \%$ & $47,3 \%$ \\
\hline Sweden & $48,5 \%$ & $57,9 \%$ & $59,3 \%$ \\
\hline United Kingdom & $39,7 \%$ & $57,4 \%$ & $62,8 \%$ \\
\hline United States & $25,1 \%$ & $33,4 \%$ & $34,1 \%$ \\
\hline
\end{tabular}

Source: World Input-Output Database (WIOD) 